\title{
Completion norms for 40 three-letter word stems
}

\author{
PETER GRAF \\ University of British Columbia, Vancouver, British Columbia, Canada \\ and \\ DIANE WILLIAMS \\ Navy Personnel Research and Development Center, San Diego, California
}

\begin{abstract}
This is a report of the completion responses for 40 three-letter word stems (e.g., ABO) produced by 100 undergraduate students at the University of California at San Diego. The report includes a list of the different words that were written as stem completions, their frequency of occurrence as completions, and their frequency of occurrence in English according to published norms. This list of materials is useful for the construction of completion tests for future investigations of direct priming phenomena, and it may provide an important covariate in the analysis of performance on completion tests. Preliminary analyses of the results reveal three primary factors that determine overall performance on a stem-completion test: word frequency, word length, and meanings per word. Analyses of the completions produced for each individual word stem, however, reveal that usually only one of these factors makes a significant contribution to performance.
\end{abstract}

Traditionally, memory research has focused on performance under conditions that require subjects to recollect previously studied items in an intentional manner. These conditions are illustrated by tests, such as recall and recognition, for which subjects are instructed to remember items that were studied in a specific prior episode. A growing number of recent studies have demonstrated, however, that memory can also be indexed by facilitated performance on tests that do not require intentional recollection, such as word completion (e.g., Graf \& Mandler, 1984; Graf, Squire, \& Mandler, 1984; Warrington \& Weiskrantz, 1968, 1974), free association (e.g., Shimamura \& Squire, 1984; Storms, 1958), word identification (e.g., Clarke \& Morton, 1983; Jacoby \& Dallas, 1981), and lexical decision (e.g., Meyer \& Schvaneveldt, 1971; Scarborough, Gerard, \& Cortese, 1979). The latter facilitations are generally known as direct priming effects (e.g., Cofer, 1967). The descriptive terms implicit and explicit have been used to distinguish between the effects of memory episodes that are revealed by performance on priming tests on the one hand and by performance on recall and recognition tests on the other hand (Graf \& Schacter, 1985; Schacter \& Graf, 1986). The importance of distinguishing between these two forms of memory is highlighted by the finding that a wide variety of experimental manipulations and subject factors have

\footnotetext{
This research was supported by the Natural Sciences and Engineering Research Council of Canada Grant UO299 to Peter Graf, a National Institute of Mental Health postdoctoral fellowship to Diane Williams, and a National Science Foundation Grant BNS 79-15336 to George Mandler. We are grateful to Robert Bryant for experimental assistance and to Kelly Nakamura for data analysis and preparation of this manuscript. Correspondence about this article should be addressed to Peter Graf, Department of Psychology, University of British Columbia, Vancouver, BC V6T 1Y7, Canada.
}

different effects on implicit and explicit memory (e.g., Eich, 1984; Graf \& Mandler, 1984; Graf \& Schacter, 1985; Howard, in press; Light, Singh, \& Capps, 1986; Roediger \& Blaxton, in press; Schacter \& Graf, 1986; Squire, Shimamura, \& Graf, 1985; Tulving, Schacter, \& Stark, 1982; Warrington \& Weiskrantz, 1968, 1974).

Word completion tests have played a prominent role in studies of implicit memory. They have been used to examine a wide range of memory phenomena in college students (e.g., Graf \& Mandler, 1984; Roediger \& Blaxton, in press; Tulving et al., 1982), to explore age changes in memory (e.g., Light et al., in press; Graf \& Schacter, 1985), and to assess the selective memory deficits of patients with organic amnesia (e.g., Diamond \& Rozin, 1984; Graf \& Schacter, 1985; Graf, Shimamura, \& Squire, 1985; Graf, Squire, \& Mandler, 1984; Squire et al., 1985; Warrington \& Weiskrantz, 1974). On completion tests, subjects are presented with word fragments (e.g., APP__, M_RT_NI, __END) and required to complete these with the first words that come to mind. These tests have two advantages over other implicit memory tests. First, completion tests enable investigators to use a paper-and-pencil format to assess priming; in contrast, other implicit memory tests, such as word identification and lexical decision, require special and expensive equipment for timing the presentation of test items and/or measuring the subjects' responses. The format of completion tests makes them inexpensive, highly portable, and, above all, usable in studies with subject populations that have different motor skills, as is the case with young and older adults, with sober and intoxicated adults, and with a variety of patients with neurological deficits (e.g., patients with Korsakoff's syndrome and Huntington's disease). A second factor that recommends completion tests is that they are very similar to 
tests that are available for assessing explicit memory, such as free and cued recall; completion and cued recall tests need to differ only in instructions (see Graf \& Mandler, 1984; Graf, Squire, \& Mandler, 1984; Schacter \& Graf, 1986). This minimal difference between test types facilitates performance comparisons between implicit and explicit memory.

On a completion test, priming is indicated by the difference in the completion frequency-the frequency of producing a particular word on the test-between words that had and words that had not been presented during a previous study trial. Consequently, the completion frequency of nonpresented words-the baseline performance-must be considered in the construction of completion tests to prevent ceiling and floor effects. Ceiling effects can be prevented by avoiding the inclusion of test items that show very high levels of baseline performance (i.e., items that would be completed by all subjects even without having recently studied the corresponding target words); floor effects can be prevented by avoiding test items that are rarely or never completed. To facilitate the selection of items that meet these criteria, as well as to gain a better understanding of factors that determine what words are written on a completion test, we have collected baseline completion data from a large group of subjects.

This report provides the frequency of occurrence of words that were written as completions of word stems, that is, the initial three letters of words (e.g., $\mathrm{ABO} \_$_ $)$. For each of the stems that were used to elicit completions, the English language includes several common words that can be written as completions (e.g., ABOUT, ABOVE, ABOLISH). Of primary interest was the frequency with which each word was produced as a completion. The use of word-stem cues that allow many different completions was motivated by considerations of the intended application of completion tests, for example, for the assessment of priming in patients with normal versus impaired memory functions. When each test cue permits several possible completions, each subject can readily come up with one completion and thus can experience the positive effects that come from succeeding on a test; this experience may be especially important to patients with cognitive deficits. In addition, when several completions are possible for each stem, priming is revealed by a bias in favor of writing recently studied words rather than nonstudied words. In contrast, for cues that have only one completion (e.g., ONI UNL ER E), priming is indicated by an increase in the proportion of cues that are completed. Using the latter cue types has a disadvantage: performance is more affected by possible response criterion differences that are frequently observed in comparisons that involve different subject groups (e.g., young vs. older adults, sober vs. intoxicated adults, normal vs. memory-impaired patients). An additional disadvantage comes from the fact that when using cues with unique completions (e.g., UNI_ER E), tests are administered under time-limited conditions (because every subject might eventually figure out the appropriate words for each cue), and thus there is the potential for the results to be confounded by between-group differences in speeded behavior.

\section{METHOD}

\section{Subjects}

The subjects were 100 undergraduates ( 56 women, 44 men) at the University of California at San Diego who participated in the experiment for partial credit in an introductory psychology course. They were tested in groups of about 12 .

\section{Materials and Procedure}

The experiment was described as examining knowledge of words. Each subject received a six-page booklet. The first page contained the instructions and a practice item. The instructions were as follows:

The following pages list 40 word beginnings and six numbered spaces next to each. Please complete each word beginning to form English words; write six different completions for each beginning. Write the first completion in the space with the number 1 , the second completion in the space with the number 2, etc. DO NOT WRITE ANY PROPER NAMES AS COMPLETIONS.

The practice item was the word stem APP. The experimenter read the instructions aloud, solicited clarifying questions from the subjects, and then let them complete the practice item. The instructions emphasized that the goal was to write six different words for each stem and gave several examples that would not be counted as different words, such as a verb in its present and past tense, a noun in its singular and plural forms, or a noun in various compound forms (e.g., APPLEPIE, APPLEJUICE). Subjects were encouraged to write words even if they were not sure of the correct spellings.

Each of the remaining five pages of the test booklet contained eight three-letter word stems with six numbered spaces next to each. Two different random orders of these 40 word stems were used across subjects. Subjects were requested to proceed through the test booklet and write the first completions that came to mind for each stem, as quickly as possible. The instructions emphasized that subjects should proceed to the next stem after about $1 \mathrm{~min}$ of trying unsuccessfully to think of additional completions for the current stem. This ensured that each subject worked on each stem at least once during the test session, which lasted about $90 \mathrm{~min}$. Subjects were encouraged to return to unfinished test items after having tried all items at least once.

\section{RESULTS AND DISCUSSION}

Of primary interest were the words that were written as stem completions, the frequency of occurrence of these words, and the number of different completions that were produced for each stem. These findings appear in the Ap- 
pendix in an alphabetically ordered list. The first column of this list shows the words that were written as completions for each stem. This column is edited and shows only common names and words that can be found in Webster's Seventh New Collegiate Dictionary (1961). The second column of the Appendix shows the frequency of occurrence of words that were written as first completions for the stems; the score is a percentage out of a maximum 100 . The third column shows the combined frequency of occurrence of words that were written in the remaining output positions, that is, as second through sixth completions for the stems; the score is also a percentage, but out of a maximum 500. The fourth and fifth columns show the frequency of occurrence of each word in the English language according to the norms of Kučera and Francis (1967) and Thorndike and Lorge (1944), respectively. In the latter norms, high-frequency words are coded as either $\mathrm{A}$ or AA. For the purpose of the present paper, $\mathrm{A}$ and AA words were assigned frequencies of 50 and 100 , respectively. Listed separately as "other completions," at the end of the completions produced for each word stem, is the total percentage of subjects who failed to write a completion and/or wrote a misspelled word or a nonword letter string for that word stem.

First completions are listed separately from the remaining completions because of the different constraints that guided the production of first and remaining completions. First completions were constrained only by the word stems that were presented as cues, whereas the production of the later completions was also constrained by the words that already had been produced (see the test instructions). The conditions for the production of first completions are most similar to the conditions that prevail on typical word completion tests, and thus the data on first completions should provide the best estimates of baseline completion performance. Moreover, in our sample, the data for first completions are more complete than the data for the remaining completions, in the sense that very few subjects failed to write at least one word for each stem. On average, the number of subjects (out of 100 ) who failed to provide a first, second, third, fourth, fifth, and sixth completion for each stem was .6, .8, 1.9, 4.7, 8.4, and 14.6, respectively. (In the Appendix, missing completions for each word stem are included under "other completions."') Despite reservations about all but the first completions, however, we collected the remaining completions because they provide a means for assessing the reliability of first completions as well as possibly revealing additional factors that influence completion test performance.

The completion test results showed a wide range in the number of different completions produced for each word stem. For some stems, only 8 different words were produced as first completions, whereas others elicited as many as 30 different first completions ( $M=18.2$ completions per word stem). For remaining completions, the range was from 20 to 81 different completions $(M=41.5$ completions per stem). Also, an average of .6 different nonword letter strings were written as first completions, and 6.3 different nonword strings were written as remaining completions. The nonword letter strings were mostly misspelled words (e.g., ACCROSS, EXPOND) that were given in the later output positions (as fourth, fifth, and sixth completions), perhaps due to failure to retrieve further words as completions.

The variability in the number of completions across the different stems may be explained by word availability, that is, the number of different words with the same stem in the English language. To examine this, we computed correlation scores between the number of different words that were written as completions for each stem and the number of different words with the same stem in (1) the Kučera and Francis (1967) norms, (2) the Thorndike and Lorge (1944) norms, and (3) Webster's Seventh New Collegiate Dictionary (1961). Only bold-printed entries were used for the last count. The results from this analysis are shown in Table 1 . Highly significant correlations $(p<$ .001 ) were obtained between the number of different first completions and entries in the Kučera and Francis norms $(r=.63)$, first completions and entries in the Thorndike and Lorge norms $(r=.71)$ and first completions and dictionary entries $(r=.74)$. The corresponding correlation scores for the remaining completions were $.78, .83$, and .80 , respectively. The fact that performance was similar across output positions (from first to sixth completions) is also implied by a high correlation between the number of different first completions and the number of different remaining completions $(r=.83)$.

What factors determine how frequently a particular word is written on the completion test? One factor that seems important is the length of a word (i.e., the number of letters or syllables in a word), as suggested by Zipf's $(1935 / 1965)$ observation that across different languages (e.g., Chinese, Latin, English) the length of a word is negatively correlated with the frequency of its usage. Zipf's law predicts a negative correlation between a word's length and its frequency of occurrence on the completion test. This prediction was confirmed by an analysis of the words that were produced as completions at each output position (i.e., for the first through the sixth completion). The relevant results are shown in Table 2 , Part 1. As is apparent from the table, similar correlations

Table 1

Correlations Among the Number of Different Words Produced as First (fFirst) Completions and Remaining (HRemaining) Completions for Each Word Stem, and the Number of Different Words with the Same Stem in the Kucera and Francis (1967) Norms (\#K\&F), the Thorndike and Lorge (1944) Norms (T\&L), and Websters's Seventh New Collegiate Dictionary (\#WCD)

\begin{tabular}{lcccc}
\hline & \#Remaining & \#K\&F & \#T\&L & \#WCD \\
\hline \#First & $.827^{*}$ & .633 & .709 & .737 \\
\#Remaining & & .776 & .832 & .801 \\
\#K\&F & & & .962 & .833 \\
\#T\&L & & & & .840 \\
\hline
\end{tabular}

$*_{n}=40, p<.001$, for each score. 
were obtained with word length measured in terms of either number of letters or number or syllables; the two measures of word length were highly correlated $(r=$ .848) in our sample.

The results in Table 2 show that from first to sixth completions, there was an increase in the strength of the correlations between frequency of production and word length. This increase may indicate that the production of first completions was constrained by different factors (primarily by the stem that was given as a test cue) from those constraining the production of the remaining completions (see instructions). Such a change could occur for several reasons; for instance, it could be a statistical anomaly caused by the fact that across output positions there was an increase in the number of different words that were produced as completions (see Table 2, Part 4).

Zipf's (1935/1965) law is also relevant to the relation between the length of words that were written as completions and their frequency of occurrence in the English language. The average length of the words that were produced at each output position and their average frequency of occurrence in the language are also shown in Table 2 , Part 4. Two estimates of language frequency were obtained, one from the norms of Kučera and Francis (1967) and the second from the norms of Thorndike and Lorge (1944). In the latter norms, high-frequency words are coded as either A or AA; for the purpose of the present analysis, they were assigned frequencies of 50 and 100 , respectively. The tabled means show that there was a significant (see $S E M$ values with means) increase in word length from first to second completions and from second to third completions, but little change in word length in the remaining output positions. In contrast, the word frequency scores showed a sharp decrease from first to second completions and from second to third completions, with smaller reductions in mean frequency across the remaining output positions. These findings are consistent with Zipf's law, which predicts that a decrease in language frequency should be accompanied by an increase in word length. Also consistent with Zipf's law, word length and normative language frequency were significantly correlated in our sample (see Table 2, Part 2).

The decrease in average language frequency across output positions points to a second factor-word familiarity or availability-that might be an important determinant of what words are written as completions. It is possible that the more familiar a word, the more likely it is that it will come to mind as a completion. A positive relation between familiarity and frequency of occurrence as a completion is suggested by Underwood and Schulz's (1960) spew hypothesis, which states that "the order of availability of verbal units is directly related to the frequency with which the units have been experienced" (p. 86). By this hypothesis, we would expect that words that are writ-

Table 2

Correlation Scores and Descriptive Statistics for Words Written as First to Sixth Completions

\begin{tabular}{|c|c|c|c|c|c|c|}
\hline & \multicolumn{6}{|c|}{ Completion Test Output Position } \\
\hline & lst & 2nd & 3rd & 4th & 5th & 6th \\
\hline \multicolumn{7}{|c|}{ Correlation Data } \\
\hline $\begin{array}{l}\text { Part } 1 \\
r \text { (test frequency, letters)* } \\
r \text { (test frequency, syllables)* }\end{array}$ & $\begin{array}{l}-.27 \\
-.21\end{array}$ & $\begin{array}{l}-.33 \\
-.27\end{array}$ & $\begin{array}{l}-.37 \\
-.30\end{array}$ & $\begin{array}{l}-.38 \\
-.32\end{array}$ & $\begin{array}{l}-.40 \\
-.34\end{array}$ & $\begin{array}{l}-.41 \\
-.36\end{array}$ \\
\hline $\begin{array}{l}\text { Part } 2 \\
\quad r \text { (K\&F frequency, letters) } \dagger \\
r \text { (T\&L frequency, letters }) \dagger\end{array}$ & $\begin{array}{l}-.15 \\
-.29\end{array}$ & $\begin{array}{l}-.12 \\
-.31\end{array}$ & $\begin{array}{l}-.12 \\
-.34\end{array}$ & $\begin{array}{l}-.11 \\
-.32\end{array}$ & $\begin{array}{l}-.11 \\
-.31\end{array}$ & $\begin{array}{l}-.10 \\
-.29\end{array}$ \\
\hline $\begin{array}{l}\text { Part } 3 \\
r(\mathrm{~K} \& \mathrm{~F} \text {, test frequency)* } \\
r(\mathrm{~T} \& \mathrm{~L}, \text { test frequency })^{*}\end{array}$ & $\begin{array}{l}.30 \\
.48\end{array}$ & $\begin{array}{l}.20 \\
.50\end{array}$ & $\begin{array}{l}.15 \\
.47\end{array}$ & $\begin{array}{l}.14 \\
.44\end{array}$ & $\begin{array}{l}.13 \\
.38\end{array}$ & $\begin{array}{l}.11 \\
.38\end{array}$ \\
\hline \multicolumn{7}{|c|}{ Descriptive Data } \\
\hline Part 4 & & & & & & \\
\hline $\begin{array}{l}\text { total \# words } \\
\# \text { of different words }\end{array}$ & $\begin{array}{r}3956 \\
730\end{array}$ & $\begin{array}{r}3971 \\
922\end{array}$ & $\begin{array}{r}3860 \\
995\end{array}$ & $\begin{array}{l}3716 \\
1027\end{array}$ & $\begin{array}{l}3566 \\
1041\end{array}$ & $\begin{array}{l}3302 \\
1045\end{array}$ \\
\hline \# of letters: mean & 5.80 & 5.96 & 6.05 & 6.07 & 6.06 & 6.07 \\
\hline SEM & .026 & .027 & .028 & .028 & .029 & .030 \\
\hline K\&F frequency: mean & 139.79 & 80.19 & 58.53 & 54.59 & 51.17 & 45.62 \\
\hline$S E M$ & 8.38 & 5.53 & 4.20 & 4.20 & 5.0 & 4.41 \\
\hline T\&L frequency: mean & 45.28 & 37.94 & 33.03 & 30.95 & 28.29 & 27.75 \\
\hline$S E M$ & .63 & .60 & .59 & .56 & .55 & .57 \\
\hline
\end{tabular}

Note- "Test frequency" refers to frequency of occurrence of words in test sample; "K\&F" and "T\&L" refer to frequency of occurrence of words in the norms of Kucera and Francis (1967) and Thorndike and Lorge (1944), respectively; "letters" and "syllables" refer to word length in terms of number of letters and syllables, respectively; "total \# words" refers to the total number of words that were written at each position; and "\# of different words" refers to the number of different words written at each position. All correlation scores are significant at $p<.001$. *for $n$, see \# of different words. tfor $n$, see total \# words. 
ten as first completions occur more frequently in the English language than words written as second through sixth completions. This expectation is supported by the findings stated in the preceding paragraph.

A related expectation based on the spew hypothesis concerns the relation between the frequency of occurrence of words on the completion test and their frequency of occurrence in the English language; these two frequency measures should show a positive correlation. The relevant correlation scores are shown in Table 2, Part 3. The tabled scores show highly significant correlations between completion frequency and language frequency for the first completions ( $r=.48$ and .30 , respectively, for the Thorndike and Lorge norms and the Kučera and Francis norms), and a decrease in the strength of these correlations across output positions. These findings are consistent with the idea that the production of a word as a completion is related to its familiarity. The decrease in correlation strengths, which may be a statistical artifact due to a change in the variance of the language frequency scores of completions (see SEM values in Table 2, Part 4), also suggests that the production of first and remaining completions was constrained by different factors. The higher correlations that were obtained with the Thorndike and Lorge norms indicate that they provide a better estimate of word familiarity for the subjects who participated in our study (see Gernsbacher, 1984, for discussion of word familiarity). This is surprising in view of the fact that the Thorndike and Lorge norms were collected 23 years earlier than the Kučera and Francis norms.

Table 3

Results from Stepwise Regression Analyses of the First Completions Produced for Each Word Stem

\begin{tabular}{|c|c|c|c|c|}
\hline Word Stem & $\begin{array}{c}\text { Number } \\
\text { of Words }\end{array}$ & $\begin{array}{c}\text { Regression } \\
F \text { Value }\end{array}$ & $\begin{array}{c}\text { Multiple } \\
r^{2}\end{array}$ & Regression Equation \\
\hline $\mathrm{ABO}$ & 9 & 48.6 & .87 & $5.2181+.0243 \mathrm{KF}$ \\
\hline $\mathrm{ACC}$ & 21 & 50.4 & .73 & $-2.4187+1.5935 \mathrm{MEA}$ \\
\hline AFF & 19 & & & \\
\hline BAN & 10 & & & \\
\hline BRI & 16 & & & \\
\hline CHA & 27 & 23.7 & .49 & $.2879+.5728 \mathrm{MEA}$ \\
\hline CLA & 18 & 13.8 & .46 & $2.7209+.0717 \mathrm{KF}$ \\
\hline $\mathrm{DEC}$ & 21 & 20.3 & .69 & $4.1496+.2087 \mathrm{TL}-1.1113 \mathrm{MEA}$ \\
\hline DEF & 20 & & & \\
\hline DEP & 19 & 21.6 & .56 & $1.3090+.1840 \mathrm{TL}$ \\
\hline DRA & 14 & & & \\
\hline EXP & 16 & 5.0 & .27 & $-12.6912+2.7059$ LEN \\
\hline FIL & 15 & 19.3 & .60 & $-1.2104+2.2145 \mathrm{MEA}$ \\
\hline FLO & 9 & 11.0 & .61 & $-6.5503+2.9799 \mathrm{MEA}$ \\
\hline FOR & 30 & 14.8 & .35 & $1.0356+.4709 \mathrm{MEA}$ \\
\hline FRA & 15 & 27.3 & .68 & $-1.0879+2.2611 \mathrm{MEA}$ \\
\hline GAR & 15 & & & \\
\hline GEN & 15 & 96.3 & .94 & $13.2224+.0732 \mathrm{KF}-1.3845$ LEN \\
\hline GRA & 26 & & & \\
\hline GRO & 16 & 7.4 & .53 & $-2.1300+.3871 \mathrm{TL}-.0784 \mathrm{KF}$ \\
\hline HAR & 20 & 14.8 & .45 & $16.3900-1.8754$ LEN \\
\hline LEA & 14 & & & \\
\hline MAR & 14 & 13.5 & .53 & $.7860+.1337 \mathrm{TL}$ \\
\hline MOR & 20 & 79.9 & .90 & $2.2352+.0078 \mathrm{KF}+.0959 \mathrm{TL}$ \\
\hline PAR & 30 & 80.9 & .74 & $1.9397+.0401 \mathrm{KF}$ \\
\hline REL & 19 & & & \\
\hline RES & 23 & 13.7 & .40 & $-.1264+1.0719 \mathrm{MEA}$ \\
\hline RET & 20 & 10.0 & .54 & $1.8292+.4168 \mathrm{TL}-.1575 \mathrm{KF}$ \\
\hline SAL & 16 & 12.2 & .47 & $1.2637+.2730 \mathrm{TL}$ \\
\hline SCA & 23 & 11.9 & .54 & $8.9092+.1709 \mathrm{TL}-1.0691$ LEN \\
\hline SCO & 18 & 35.2 & .69 & $2.1594+.4625 \mathrm{KF}$ \\
\hline SHA & 21 & & & \\
\hline SHO & 15 & 6.2 & .32 & 47.2917 - 8.1250 LEN \\
\hline SPI & 13 & 5.9 & .35 & $25.7778-3.4722$ LEN \\
\hline TEN & 16 & 8.6 & .38 & $3.1734+.1772 \mathrm{TL}$ \\
\hline THI & 12 & 59.5 & .93 & $1.9549+.0049 \mathrm{KF}+.5743 \mathrm{MEA}$ \\
\hline THR & 15 & 20.9 & .78 & $-.8078+.0170 \mathrm{KF}+.8551 \mathrm{MEA}$ \\
\hline TRA & 21 & 26.3 & .58 & $1.2283+.1119 \mathrm{TL}$ \\
\hline TRI & 27 & 5.7 & .19 & $1.8959+.3657$ MEA \\
\hline WEA & 13 & 8.7 & .44 & $.8458+1.3385$ MEA \\
\hline
\end{tabular}

Note-For the regression equations, "K\&F" and "T\&L" refer to frequency of occurrence of words in the norms of Kucera and Francis (1967) and Thorndike and Lorge (1944), respectively; "LEN" refers to word length in terms of numbers of letters; "MEA" refers to meanings per word as estimated on the basis of numbered entries in Webster's Seventh New Collegiate Dictionary. No statistics are reported for word stems that did not show significant regression results. 
Can the factors considered in the foregoing paragraphs, either alone or together, or in combination with additional factors, predict the frequency of occurrence of words that were written as first completions? This question was examined in overall regression analyses that used language frequency (both Kučera \& Francis [KF], and Thorndike \& Lorge [TL]), word length (length in letters [LENGTH] only since it was highly correlated with length in syllables), and meanings per word [MEAN] to predict frequency of first completions. The number of meanings per word was estimated on the basis of the numbered entries for each word in Webster's Seventh New Collegiate Dictionary. The regression equation, calculated from the results of a stepwise analysis, was:

$$
\begin{aligned}
\text { freq. (first) } & =6.145+.0593 \mathrm{TL}+.0061 \mathrm{KF} \\
& -.5488 \mathrm{LENGTH}+.2164 \mathrm{MEAN} .
\end{aligned}
$$

This equation had a significant multiple $r^{2}$ of $.22[F(4,716)$ $=50.1, p<.001]$. Several completions, especially those that have a high frequency of occurrence $(>.30)$, were not predicted well by this equation; however, their removal from the data did not significantly increase the predictive power of the equation. Similarly, there was no significant increase in predictive power when the analysis was based on the log-transformed scores for language frequency and/or for completion frequency. The results from this analysis are consistent with the observations of Zipf (1935) and of Underwood and Schulz (1960). What is surprising, perhaps, is the small portion of variance in frequency of first completions that is accounted for by this overall regression analysis.

A separate stepwise regression analysis involving the same four factors was also conducted on the completion responses that were written for each word stem. Table 3 shows the results from these analyses, including the number of different words that entered into each analysis, the $F$ and $r^{2}$ statistics, and the regression equation for each word stem. Significant regression results were found with 30 of the $\mathbf{4 0}$ word stems. In contrast to the results from the overall regression analysis that used four factors and had a low multiple $r^{2}$, however, the individual analysis had considerably higher multiple $r^{2}$ values, ranging from .19 to .94 , and typically involved only one factor, either number of word meanings or language frequency. These findings suggest that for at least some word stems, baseline completion performance can be estimated with the aid of normative data. (In our sample, the number of meanings per word was highly correlated with Kučera and Francis's frequency $[r=.16]$ and Thorndike and Lorge's frequency $[r=.58]$.)

To conclude, the results reported in this paper provide normative data on word completions produced for a large set of three-letter word stems and reveal some factors that determine the frequency of such completions. The results can be used as a database for selecting target words for the construction of completion tests, and to guide the selection of new words for such tests. These data could also be used to manipulate baseline performance across ex- perimental conditions, or they can be used as covariates in data analyses.

\section{REFERENCES}

Clark, R., \& Morton, J. (1983). Cross modality facilitation in tachistoscopic word recognition. Quarterly Journal of Experimental Psychology, 35A, 79-96.

Cofre, C. C. (1967). Conditions for the use of verbal associations. Psychological Bulletin, 68, 1-12.

DiAmond, R., \& Rozin, P. (1984). Activation of existing memories in the amnesic syndrome. Journal of Abnormal Psychology, 93, 98-105.

EICH, J. E. (1984). Memory for unattended events: Remembering with and without awareness. Memory \& Cognition, 12, 105-111.

GERNSBACHER, M. A. (1984). Resolving 20 years of inconsistent interactions between lexical familiarity and orthography, concreteness, and polysemy. Journal of Experimental Psychology: General, 113, 256-281.

GraF, P., MANDler, G. (1984). Activation makes words more accessible but not necessarily more retrievable. Joumal of Verbal Leaming \& Verbal Behavior, 23, 553-568.

Graf, P., \& SChaCter, D. L. (1985). Implicit and explicit memory for new associations in normal and amnesic subjects. Journal of Experimental Psychology: Learning, Memory, \& Cognition, 11, 501-518.

Graf, P., Shimamura, A. P., \& Souire, L. R. (1985). Priming across modalities and priming across category levels: Extending the domain of preserved function in amnesia. Journal of Experimental Psychology: Learning, Memory, \& Cognition, 11, 386-396.

GraF, P., SQuire, L. R., \& MaNdler, G. (1984). The information that amnesic patients do not forget. Journal of Experimental Psychology: Learning, Memory, \& Cognition, 10, 164-178.

How ARD, D. V. (in press). Aging and memory activation: The priming of semantic and episodic memories. In L. L. Light \& D. M. Burke (Eds.), Language, memory, and aging. New York: Cambridge University Press.

JACOBY, L. L., \& DALIAS, M. (1981). On the relationship between autobiographical memory and perceptual learning. Journal of Experimental Psychology: General, 110, 306-340.

KuČERA, M., \& FrANCIS, W. (1967). Computational analysis of presentday American English. Providence, RI: Brown University Press.

Light, L. L., Singh, A., \& CAPPS, J. L. (1986). Dissociation of memory and awareness in young and older adults. Journal of Clinical Neuropsychology, 8, 62-74.

Meyer, D. E., \&ChVANEVELDT, R. W. (1971). Facilitation in recognizing pairs of words: Evidence of a dependence between retrieval operations. Journal of Experimental Psychology, 90, 227-234.

RoEdiger, H. L., III., \& Blaxton, T. A. (in press). Retrieval modes produce dissociations in memory for surface information. In D. S. Gorfein \& R. R. Hoffman (Eds.), Memory and cognitive processes: The Ebbinghaus Centennial Conference. Hillsdale, NJ: Erlbaum.

Scarborough, D. L., Gerard, L., \& CorTese, C. (1979). Accessing lexical memory: The transfer of word repetition effects across task and modality. Memory \& Cognition, 7, 3-12.

SCHACTER, D. L., \& GRAF, P. (1986). Effects of elaborative processing on implicit and explicit memory for new associations. Journal of Experimental Psychology: Learning, Memory, \& Cognition, 12, 432-444.

Shimamura, A. P., \& Souire, L. R. (1984). Paired-associate learning and priming effects in amnesia: A neuropsychological study. Journal of Experimental Psychology: General, 113, 556-570.

Squire, L. R., Shimamura, A. P., \& Graf, P. (1985). Independence of recognition memory and priming effects: A neuropsychological analysis. Journal of Experimental Psychology: Learning, Memory, \& Cognition, 11, 37-44.

STorms, L. H. (1958). Apparent backward associations: A situational effect. Journal of Experimental Psychology, 55, 390-395.

THORNDIKE, E. L., \& LORGE, I. (1944). The teacher's word book of 
30,000 words. New York: Teachers College Press, Columbia University.

Tulving, E., Schacter, D. L., \& Stark, H. A. (1982). Priming effects in word-fragment completion are independent of recognition memory. Journal of Experimental Psychology: Learning, Memory, \& Cognition, 8, 336-342.

UNDERWOOD, B. J., \& SCHULZ, R. W. (1960). Meaningfulness and verbal learning. Philadelphia: Lippincott.

Warrington, E. K., \& WeISKRANTZ, L. (1968). New method of test- ing long-term retention with special reference to amnesic patients. Nature, 217, 972-974.

Warrington, E. K., \& Weiskrantz, L. (1974). The effect of prior learning on subsequent retention in amnesic patients. Neuropsychologia, 12, 419-428.

Webster's Seventh New Collegiate Dictionary. (1961). Springfield, MA: G \& C Merriam Co.

ZIPF, G. K. (1965). The psychobiology of language. Cambridge, MA: MIT Press. (Originally published 1935)

\section{APPENDIX}

A list of the words that were written as completions for $\mathbf{4 0}$ three-letter word stems. Shown next to each word are its frequency of occurrence as a first completion (as a percentage out of a maximum 100); the combined frequency of its occurrence as a second, third, fourth, fifth, and sixth completion (as a percentage out of a maximum 500); and its frequency of occurrence in the norms of Kučera and Francis (1967) and Thorndike \& Lorge (1944). For the purpose of data analysis, words appearing as A and AA in the Thorndike and Lorge norms were assigned frequencies of 50 and 100 , respectively.

\begin{tabular}{|c|c|c|c|c|c|c|c|c|c|}
\hline \multirow[b]{2}{*}{ Word } & \multicolumn{4}{|c|}{ Frequency } & \multirow[b]{2}{*}{ Word } & \multicolumn{4}{|c|}{ Frequency } \\
\hline & $\begin{array}{c}\text { 1st } \\
\text { Comp. }\end{array}$ & $\begin{array}{c}\text { 2nd-6th } \\
\text { Comp. }\end{array}$ & K\& & F T\&L & & $\begin{array}{c}\text { 1st } \\
\text { Comp. }\end{array}$ & $\begin{array}{c}\text { 2nd-6th } \\
\text { Comp. }\end{array}$ & K\&F & F T\&L \\
\hline aboard & 0 & 7.0 & 25 & 21 & accessory & 2 & 0.4 & 1 & 8 \\
\hline abode & 6 & 9.0 & 4 & 16 & accident & 8 & 4.4 & 33 & 50 \\
\hline abolish & 18 & 10.8 & 8 & 18 & accidental & 0 & 0.4 & 9 & 7 \\
\hline abolition & 2 & 4.8 & 10 & 7 & accidentally & 0 & 0.2 & 6 & 4 \\
\hline abolitionist & 0 & 0.2 & 1 & 1 & acclaim & 3 & 6.0 & 4 & 5 \\
\hline abominable & 0 & 5.0 & 0 & 6 & acclimate & 0 & 0.8 & 0 & 0 \\
\hline abominate & 0 & 0.6 & 0 & 0 & acclimated & 0 & 0.2 & 0 & 0 \\
\hline abomination & 0 & 2.0 & 0 & 2 & accommodate & 1 & 2.4 & 14 & 11 \\
\hline abor & 0 & 0.2 & 0 & 0 & accommodation & 0 & 0.2 & 1 & 9 \\
\hline aboriginal & 0 & 0.4 & 1 & 2 & accompany & 0 & 2.2 & 8 & 50 \\
\hline aborigine & 0 & 2.8 & 7 & 0 & accomplice & 0 & 0.6 & 2 & 2 \\
\hline aborigines & 0 & 0.2 & 8 & 1 & accomplish & 1 & 2.6 & 24 & 50 \\
\hline abort & 8 & 7.6 & 0 & 0 & accord & 3 & 6.2 & 9 & 24 \\
\hline abortion & 10 & 7.2 & 6 & 0 & accordance & 1 & 0.2 & 20 & 11 \\
\hline abortive & 0 & 0.2 & 3 & 1 & according & 2 & 0.6 & 139 & 100 \\
\hline abound & 1 & 8.4 & 1 & 12 & accordingly & 1 & 0.6 & 31 & 26 \\
\hline abounding & 0 & 0.2 & 1 & 0 & accordion & 0 & 0.2 & 1 & 1 \\
\hline about & 51 & 7.0 & 1815 & 100 & $\operatorname{accos} t$ & 1 & 0.8 & 0 & 2 \\
\hline above & 2 & 9.0 & 296 & 100 & account & 32 & 5.4 & 117 & 100 \\
\hline \multirow[t]{2}{*}{ other comp. } & 2 & 17.6 & - & - & accountable & 0 & 0.4 & 1 & 1 \\
\hline & & & & & accountant & 0 & 1.0 & 2 & 2 \\
\hline accede & 1 & 1.0 & 1 & 1 & accounting & 2 & 0.2 & 12 & 0 \\
\hline accelerate & 8 & 4.8 & 5 & 3 & accredit & 1 & 3.4 & 0 & 1 \\
\hline acceleration & 0 & 0.2 & 17 & 1 & accreditation & 0 & 0.2 & 7 & 0 \\
\hline accelerator & 0 & 0.4 & 5 & 1 & accredited & 0 & 0.6 & 0 & 0 \\
\hline accent & 12 & 6.4 & 9 & 16 & accretion & 0 & 0.2 & 3 & 0 \\
\hline accentuate & 1 & 3.6 & 1 & 3 & accrual & 0 & 0.2 & 0 & 0 \\
\hline accept & 9 & 8.0 & 72 & 100 & accrue & 0 & 2.0 & 0 & 2 \\
\hline acceptable & 0 & 0.4 & 21 & 5 & accrued & 0 & 0.2 & 3 & 0 \\
\hline acceptance & 0 & 0.4 & 49 & 11 & accumulate & 2 & 2.4 & 3 & 17 \\
\hline accepted & 0 & 0.2 & 96 & 0 & accumulation & 0 & 0.2 & 11 & 5 \\
\hline acception & 0 & 0.4 & 0 & 0 & accurate & 0 & 1.6 & 35 & 14 \\
\hline access & 6 & 3.4 & 24 & 11 & accurse & 0 & 0.2 & 0 & 0 \\
\hline accessible & 0 & 1.0 & 5 & 5 & accusation & 0 & 0.4 & 3 & 9 \\
\hline
\end{tabular}




\begin{tabular}{|c|c|c|c|c|c|c|c|c|c|}
\hline \multirow[b]{2}{*}{ Word } & \multicolumn{4}{|c|}{ Frequency } & \multirow[b]{2}{*}{ Word } & \multicolumn{4}{|c|}{ Frequency } \\
\hline & $\begin{array}{c}\text { 1st } \\
\text { Comp. }\end{array}$ & $\begin{array}{l}\text { 2nd-6th } \\
\text { Comp. }\end{array}$ & K\&F & T\&L & & $\begin{array}{c}\text { 1st } \\
\text { Comp. }\end{array}$ & $\begin{array}{l}\text { 2nd-6th } \\
\text { Comp. }\end{array}$ & K\&F & F T\&L \\
\hline accuse & 2 & 2.0 & 10 & 26 & bangle & 0 & 0.4 & 0 & 0 \\
\hline accustom & 0 & 1.6 & 0 & 45 & banish & 12 & 5.8 & 4 & 16 \\
\hline accustomed & 0 & 0.2 & 15 & 0 & banister & 1 & 3.8 & 5 & 1 \\
\hline \multirow[t]{2}{*}{ other comp. } & 1 & 17.8 & - & - & banjo & 0 & 1.8 & 2 & 2 \\
\hline & & & & & bank & 4 & 13.0 & 83 & 100 \\
\hline affable & 7 & 3.4 & 1 & 3 & banker & 0 & 0.6 & 5 & 27 \\
\hline affair & 10 & 2.4 & 33 & 100 & bankrupt & 0 & 0.4 & 5 & 6 \\
\hline affect & 12 & 8.2 & 35 & 50 & banned & 0 & 1.6 & 2 & 0 \\
\hline affectation & 0 & 0.6 & 1 & 3 & banner & 32 & 8.8 & 8 & 23 \\
\hline affected & 0 & 0.2 & 36 & 0 & banning & 0 & 0.4 & 1 & 0 \\
\hline affection & 2 & 5.2 & 18 & 37 & bannister & 0 & 0.2 & 0 & 0 \\
\hline affectionate & 1 & 1.2 & 6 & 12 & banquet & 1 & 3.4 & 6 & 18 \\
\hline affective & 0 & 0.8 & 0 & 0 & bans & 0 & 0.2 & 1 & 0 \\
\hline afferent & 3 & 0.6 & 1 & 0 & banshee & 0 & 0.6 & 1 & 0 \\
\hline afficionado & 1 & 0.2 & 0 & 0 & bant & 0 & 0.4 & 0 & 0 \\
\hline affidavit & 2 & 2.6 & 0 & 1 & bantam & 1 & 0.6 & 0 & 0 \\
\hline affiliate & 23 & 3.8 & 0 & 2 & banter & 0 & 8.0 & 5 & 3 \\
\hline affiliated & 0 & 0.4 & 7 & 0 & bantu & 0 & 0.2 & 1 & 0 \\
\hline affiliation & 2 & 1.2 & 4 & 1 & banty & 0 & 0.2 & 1 & 0 \\
\hline affinitive & 0 & 0.6 & 0 & 0 & banyan & 0 & 0.2 & 0 & 0 \\
\hline affinity & 1 & 1.4 & 5 & 5 & other comp. & 1 & 6.8 & - & - \\
\hline affirm & 11 & 5.6 & 12 & 10 & & & & & \\
\hline affirmation & 0 & 1.0 & 4 & 1 & briar & 0 & 0.6 & 1 & 5 \\
\hline affirmative & 2 & 2.2 & 4 & 3 & briars & 0 & 0.2 & 0 & 0 \\
\hline affix & 1 & 4.2 & 1 & 2 & bribe & 4 & 8.2 & 1 & 10 \\
\hline affixation & 0 & 0.4 & 0 & 0 & bribery & 0 & 0.2 & 0 & 2 \\
\hline affixiate & 0 & 1.0 & 0 & 0 & brick & 5 & 9.2 & 18 & 49 \\
\hline afflict & 1 & 6.0 & 0 & 9 & bricks & 0 & 0.2 & 6 & 0 \\
\hline affliction & 2 & 1.0 & 1 & 4 & bridal & 0 & 0.6 & 2 & 5 \\
\hline affluence & 1 & 2.2 & 4 & 1 & bride & 15 & 7.2 & 33 & 41 \\
\hline affluent & 11 & 6.4 & 2 & 2 & bridge & 1 & 5.8 & 98 & 100 \\
\hline af ford & 6 & 8.8 & 40 & 50 & bridging & 0 & 0.2 & 0 & 0 \\
\hline affordable & 0 & 1.8 & 0 & 0 & bridle & 0 & 3.2 & 1 & 18 \\
\hline affray & 0 & 0.2 & 0 & 1 & brie & 0 & 0.4 & 0 & 0 \\
\hline affront & 1 & 4.4 & 2 & 4 & brief & 2 & 2.8 & 73 & 50 \\
\hline \multirow[t]{2}{*}{ other comp. } & 0 & 21.8 & - & - & brier & 0 & 0.4 & 0 & 6 \\
\hline & & & & & brig & 0 & 2.2 & 2 & 2 \\
\hline banal & 1 & 3.6 & 2 & 0 & brigade & 0 & 2.2 & 3 & 8 \\
\hline banana & 8 & 6.2 & 4 & 13 & brigadier & 0 & 0.2 & 7 & 3 \\
\hline band & 35 & 11.0 & 53 & 50 & brigand & 0 & 0.4 & 0 & 2 \\
\hline bandage & 0 & 2.6 & 4 & 14 & bright & 43 & 7.6 & 87 & 100 \\
\hline bandages & 0 & 0.2 & 3 & 0 & brill & 0 & 0.6 & 0 & 0 \\
\hline bandaid & 2 & 2.8 & 0 & 0 & brilliant & 7 & 6.0 & 50 & 42 \\
\hline bandana & 0 & 3.6 & 0 & 0 & brim & 1 & 8.6 & 4 & 13 \\
\hline bandit & 0 & 3.0 & 3 & 5 & brimming & 0 & 0.4 & 0 & 0 \\
\hline bandito & 0 & 0.2 & 0 & 0 & brimstone & 0 & 0.2 & 0 & 2 \\
\hline bandwagon & 0 & 0.2 & 1 & 0 & brindle & 0 & 0.2 & 1 & 0 \\
\hline bandy & 0 & 0.2 & 0 & 1 & brine & 3 & 4.0 & 0 & 3 \\
\hline bane & 2 & 3.0 & 0 & 5 & bring & 6 & 5.8 & 158 & 100 \\
\hline bang & 0 & 6.2 & 7 & 14 & brink & 3 & 2.2 & 3 & 8 \\
\hline
\end{tabular}




\begin{tabular}{|c|c|c|c|c|c|c|c|c|c|}
\hline \multirow[b]{2}{*}{ Word } & \multicolumn{4}{|c|}{ Frequency } & \multirow[b]{2}{*}{ Word } & \multicolumn{4}{|c|}{ Frequency } \\
\hline & $\begin{array}{c}\text { 1st } \\
\text { Comp. }\end{array}$ & $\begin{array}{c}\text { 2nd-6th } \\
\text { Comp. }\end{array}$ & K\&! & F T\&L & & $\begin{array}{c}\text { 1st } \\
\text { Comp. }\end{array}$ & $\begin{array}{c}\text { 2nd-6th } \\
\text { Comp. }\end{array}$ & K\&F & F T\&L \\
\hline briny & 1 & 0.6 & 0 & 0 & charismatic & 0 & 0.2 & 0 & 0 \\
\hline brisk & 0 & 3.2 & 7 & 9 & charitable & 0 & 0.2 & 5 & 6 \\
\hline bristle & 1 & 3.0 & 3 & 11 & charity & 3 & 1.2 & 8 & 36 \\
\hline bristol & 0 & 0.2 & 3 & 3 & charlatan & 0 & 0.2 & 0 & 1 \\
\hline britain & 1 & 0.2 & 55 & 44 & charm & 3 & 2.0 & 26 & 50 \\
\hline britches & 0 & 0.2 & 1 & 0 & charming & 0 & 0.4 & 24 & 31 \\
\hline british & 2 & 0.6 & 118 & 100 & charred & 0 & 0.8 & 1 & 0 \\
\hline brittle & 5 & 5.6 & 3 & 6 & chart & 1 & 4.4 & 22 & 15 \\
\hline other comp. & 0 & 6.6 & - & - & charter & 0 & 1.0 & 33 & 20 \\
\hline & & & & & chartreuse & 0 & 0.2 & 0 & 0 \\
\hline chafe & 0 & 3.0 & 1 & 5 & chase & 11 & 6.4 & 18 & 48 \\
\hline chaff & 0 & 0.6 & 0 & 7 & chased & 0 & 0.2 & 1 & 0 \\
\hline chaffed & 0 & 0.2 & 0 & 0 & chaser & 0 & 0.2 & 0 & 0 \\
\hline chaffing & 0 & 0.2 & 1 & 0 & chasm & 0 & 0.4 & 2 & 6 \\
\hline chafing & 0 & 0.2 & 2 & 0 & chassis & 0 & 0.4 & 1 & 1 \\
\hline chagrin & 0 & 0.6 & 4 & 3 & chaste & 0 & 1.2 & 0 & 6 \\
\hline chain & 3 & 5.0 & 50 & 50 & chasten & 0 & 0.2 & 0 & 2 \\
\hline chair & 10 & 3.0 & 66 & 100 & chastise & 0 & 1.2 & 0 & 3 \\
\hline chairman & 0 & 0.2 & 67 & 22 & chastity & 1 & 1.8 & 2 & 2 \\
\hline chaise & 0 & 0.2 & 1 & 2 & chat & 4 & 5.0 & 5 & 12 \\
\hline chalice & 0 & 0.8 & 0 & 3 & chatter & 6 & 1.6 & 7 & 23 \\
\hline chalk & 4 & 4.0 & 3 & 13 & chauffeur & 0 & 0.2 & 4 & 9 \\
\hline challenge & 5 & 4.4 & 36 & 25 & chauvinist & 0 & 0.2 & 0 & 0 \\
\hline challenger & 0 & 0.2 & 1 & 1 & other comp. & 0 & 2.6 & - & - \\
\hline chamber & 0 & 1.2 & 46 & 50 & & & & & \\
\hline chamois & 0 & 0.4 & 1 & 1 & clack & 0 & 1.8 & 0 & 1 \\
\hline champ & 1 & 1.8 & 1 & 2 & clad & 0 & 6.0 & 7 & 23 \\
\hline champagne & 1 & 0.6 & 13 & 4 & claim & 2 & 5.8 & 98 & 100 \\
\hline champion & 0 & 1.8 & 23 & 36 & clai rvoyance & 0 & 0.8 & 1 & 0 \\
\hline chance & 3 & 3.6 & 131 & 100 & clairvoyant & 1 & 1.6 & 1 & 0 \\
\hline chance11or & 0 & 0.4 & 14 & 11 & clam & 16 & 9.6 & 3 & 7 \\
\hline chandelier & 0 & 0.4 & 3 & 3 & clammy & 1 & 0.2 & 2 & 1 \\
\hline chandler & 0 & 0.2 & 32 & 0 & clamor & 1 & 3.6 & 2 & 14 \\
\hline change & 15 & 6.6 & 240 & 100 & clamour & 0 & 0.2 & 0 & 0 \\
\hline channe1 & 3 & 1.8 & 16 & 35 & clamp & 2 & 4.0 & 0 & 4 \\
\hline chant & 1 & 1.0 & 2 & 16 & clams & 0 & 0.2 & 2 & 0 \\
\hline chap & 5 & 5.2 & 5 & 14 & clan & 5 & 7.4 & 2 & 8 \\
\hline chapel & 2 & 1.4 & 20 & 25 & clandestine & 0 & 0.8 & 1 & 1 \\
\hline chaperone & 0 & 0.4 & 1 & 3 & clang & 1 & 0.8 & 1 & 7 \\
\hline chaplain & 0 & 0.2 & 5 & 8 & clank & 0 & 1.4 & 0 & 2 \\
\hline chapped & 2 & 2.0 & 0 & 0 & clap & 12 & 11.8 & 1 & 22 \\
\hline chaps & 2 & 0.6 & 1 & 0 & clapboard & 0 & 0.2 & 0 & 1 \\
\hline chapter & 4 & 2.6 & 74 & 50 & clapper & 0 & 0.2 & 0 & 1 \\
\hline char & 2 & 2.8 & 1 & 3 & claque & 0 & 0.2 & 0 & 0 \\
\hline character & 1 & 1.0 & 118 & 100 & clarify & 9 & 4.0 & 13 & 1 \\
\hline charade & 0 & 0.4 & 0 & 0 & clarinet & 2 & 1.2 & 1 & 0 \\
\hline charcoal & 1 & 2.4 & 14 & 11 & clarity & 2 & 1.6 & 28 & 1 \\
\hline charge & 5 & 4.4 & 122 & 100 & clash & 7 & 2.6 & 5 & 12 \\
\hline chariot & 0 & 1.2 & 3 & 18 & clasp & 0 & 4.2 & 0 & 27 \\
\hline charisma & 1 & 0.2 & 1 & 0 & class & 23 & 8.2 & 207 & 100 \\
\hline
\end{tabular}




\begin{tabular}{|c|c|c|c|c|c|c|c|c|c|}
\hline \multirow[b]{2}{*}{ Word } & \multicolumn{4}{|c|}{ Frequency } & \multirow[b]{2}{*}{ Word } & \multicolumn{4}{|c|}{ Frequency } \\
\hline & $\begin{array}{c}\text { 1st } \\
\text { Comp. }\end{array}$ & $\begin{array}{c}\text { 2nd-6th } \\
\text { Comp. }\end{array}$ & $K \& F$ & $T \& L$ & & $\begin{array}{c}\text { 1st } \\
\text { Comp. }\end{array}$ & $\begin{array}{c}\text { 2nd-6th } \\
\text { Comp. }\end{array}$ & $K \& F$ & F T\&L \\
\hline classes & 0 & 0.2 & 85 & 0 & decision & 2 & 2.8 & 119 & 46 \\
\hline classic & 1 & 0.6 & 36 & 15 & decisions & 0 & 0.2 & 54 & 0 \\
\hline classification & 1 & 0.4 & 21 & 6 & decisive & 0 & 0.6 & 19 & 8 \\
\hline classify & 0 & 2.0 & 6 & 6 & deck & 6 & 6.2 & 23 & 50 \\
\hline classroom & 0 & 0.4 & 18 & 3 & declaim & 0 & 0.2 & 0 & 1 \\
\hline classy & 0 & 0.2 & 0 & 0 & declaration & 0 & 0.4 & 24 & 18 \\
\hline clatter & 0 & 4.4 & 2 & 15 & declare & 0 & 2.6 & 8 & 100 \\
\hline claude & 0 & 0.2 & 11 & 0 & declassify & 0 & 0.2 & 0 & 0 \\
\hline clause & 4 & 1.0 & 9 & 9 & decline & 2 & 3.6 & 31 & 50 \\
\hline claustrophobia & 0 & 0.2 & 1 & 0 & decode & 0 & 4.0 & 0 & 0 \\
\hline clave & 0 & 0.2 & 0 & 0 & decolor & 0 & 0.2 & 0 & 0 \\
\hline clavicle & 0 & 1.8 & 0 & 0 & decompose & 1 & 1.8 & 1 & 6 \\
\hline claw & 1 & 2.2 & 1 & 23 & decompress & 0 & 0.2 & 0 & 0 \\
\hline clay & 8 & $4 \cdot 2$ & 100 & 43 & decongest & 0 & 0.2 & 0 & 0 \\
\hline other comp. & 1 & 3.6 & - & - & decontaminate & 0 & 0.2 & 0 & 0 \\
\hline & & & & & decontrol & 0 & 0.4 & 0 & 0 \\
\hline decade & 3 & 5.0 & 46 & 13 & decor & 1 & 0.8 & 4 & 0 \\
\hline decadence & 1 & 1.6 & 2 & 1 & decorate & 6 & 3.8 & 2 & 17 \\
\hline decadent & 3 & 4.0 & 2 & 0 & decoration & 0 & 0.4 & 8 & 19 \\
\hline decaffeinated & 0 & 0.4 & 0 & 0 & decorous & 0 & 0.4 & 1 & 1 \\
\hline decagon & 0 & 0.2 & 0 & 0 & decorum & 0 & 0.4 & 2 & 2 \\
\hline decagram & 0 & 0.2 & 0 & 0 & decoupage & 0 & 0.4 & 0 & 0 \\
\hline decal & 0 & 1.2 & 0 & 0 & decoy & 0 & 1.2 & 0 & 3 \\
\hline decaliter & 0 & 0.4 & 0 & 0 & decrease & 2 & 1.2 & 15 & 25 \\
\hline decameter & 0 & 0.4 & 0 & 0 & decree & 0 & 1.2 & 3 & 20 \\
\hline decant & 0 & 0.6 & 0 & 0 & decrement & 0 & 0.4 & 2 & 0 \\
\hline decanter & 0 & 3.2 & 0 & 0 & decrepit & 0 & 1.0 & 0 & 1 \\
\hline decapitate & 0 & 1.0 & 0 & 0 & decry & 0 & 1.8 & 2 & 1 \\
\hline decay & 0 & 2.2 & 14 & 33 & other comp. & 2 & 9.0 & - & - \\
\hline decease & 0 & 1.2 & 0 & 4 & & & & & \\
\hline deceased & 0 & 0.6 & 10 & 4 & deface & 2 & 4.4 & 0 & 2 \\
\hline decedent & 1 & 0.8 & 2 & 0 & defamation & 0 & 0.4 & 0 & 0 \\
\hline deceit & 1 & 2.0 & 2 & 8 & defame & 1 & 2.2 & 0 & 1 \\
\hline deceive & 1 & 2.6 & 1 & 33 & default & 0 & 2.8 & 2 & 2 \\
\hline decelerate & 0 & 0.2 & 1 & 0 & defeat & 1 & 3.4 & 31 & 50 \\
\hline december & 21 & 1.8 & 62 & 50 & defecate & 0 & 2.6 & 0 & 0 \\
\hline decency & 0 & 0.6 & 10 & 5 & defect & 2 & 2.6 & 3 & 14 \\
\hline decent & 3 & 3.6 & 20 & 18 & defence & 0 & 0.2 & 1 & 25 \\
\hline deception & 0 & 0.2 & 1 & 4 & defend & 12 & 5.8 & 21 & 50 \\
\hline decertify & 0 & 0.2 & 1 & 0 & defender & 0 & 0.4 & 3 & 7 \\
\hline decibel & 5 & 3.4 & 0 & 0 & defense & 10 & 2.2 & 167 & 25 \\
\hline decibels & 0 & 0.2 & 0 & 0 & defensible & 0 & 0.2 & 3 & 0 \\
\hline decide & 24 & 8.2 & 40 & 100 & defensive & 0 & 0.6 & 17 & 8 \\
\hline deciding & 1 & 0.0 & 12 & 0 & defer & 4 & 3.8 & 1 & 7 \\
\hline deciduous & 0 & 0.8 & 0 & 1 & deference & 2 & 0.6 & 5 & 4 \\
\hline deciliter & 0 & 0.2 & 0 & 0 & deferent & 0 & 0.2 & 0 & 0 \\
\hline decimal & 9 & 2.8 & 3 & 1 & deferral & 0 & 0.2 & 0 & 0 \\
\hline decimate & 2 & 1.0 & 0 & 0 & deferred & 0 & 0.4 & 1 & 0 \\
\hline decimeter & 1 & 1.2 & 0 & 0 & defiance & 1 & 0.6 & 7 & 12 \\
\hline decipher & 2 & 2.4 & 0 & 2 & defiant & 0 & 1.4 & 3 & 4 \\
\hline
\end{tabular}




\begin{tabular}{|c|c|c|c|c|c|c|c|c|c|}
\hline \multirow[b]{2}{*}{ Word } & \multicolumn{4}{|c|}{ Frequency } & \multirow[b]{2}{*}{ Word } & \multicolumn{4}{|c|}{ Frequency } \\
\hline & $\begin{array}{c}\text { 1st } \\
\text { Comp. }\end{array}$ & $\begin{array}{l}\text { 2nd-6th } \\
\text { Comp. }\end{array}$ & K\&F & $T \& L$ & & $\begin{array}{c}\text { 1st } \\
\text { Comp. }\end{array}$ & $\begin{array}{c}\text { 2nd-6th } \\
\text { Comp. }\end{array}$ & K\&F & $T \& L$ \\
\hline deficient & 1 & 0.2 & 3 & 5 & depopulate & 0 & 0.2 & 0 & 0 \\
\hline deficit & 1 & 3.0 & 12 & 4 & deport & 6 & 7.0 & 1 & 2 \\
\hline defies & 0 & 0.2 & 0 & 0 & deportation & 1 & 0.2 & 0 & 3 \\
\hline defile & 2 & 3.0 & 0 & 6 & deportment & 0 & 0.2 & 0 & 4 \\
\hline define & 23 & 5.8 & 27 & 19 & depose & 0 & $1 \cdot 6$ & 1 & 5 \\
\hline defined & 0 & 0.2 & 39 & 0 & deposit & 2 & 6.0 & 9 & 41 \\
\hline definite & 10 & 7.0 & 37 & 33 & deposition & 0 & 3.0 & 3 & 2 \\
\hline definitely & 1 & 1.0 & 21 & 23 & depot & 2 & 5.2 & 13 & 8 \\
\hline definition & 20 & 3.8 & 38 & 9 & deprave & 1 & 0.8 & 0 & 0 \\
\hline definitive & 1 & 1.6 & 5 & 1 & depraved & 0 & 0.6 & 2 & 1 \\
\hline deflate & 0 & 1.6 & 0 & 0 & deprecate & 0 & 0.6 & 0 & 1 \\
\hline deflect & 0 & 1.2 & 0 & 1 & depreciate & 1 & 5.8 & 0 & 3 \\
\hline deflower & 0 & 1.4 & 0 & 0 & depreciation & 0 & 0.2 & 12 & 0 \\
\hline deflux & 0 & 0.2 & 0 & 0 & depress & 2 & 1.6 & 1 & 8 \\
\hline defoliate & 0 & 0.2 & 0 & 0 & depressed & 0 & 0.2 & 11 & 3 \\
\hline deform & 0 & 5.6 & 0 & 2 & depressing & 0 & 0.4 & 5 & 0 \\
\hline deformed & 0 & 1.0 & 0 & 3 & depression & 1 & 1.2 & 24 & 25 \\
\hline defraud & 0 & 1.6 & 2 & 2 & deprival & 0 & 0.2 & 0 & 0 \\
\hline defrock & 0 & 0.2 & 0 & 0 & deprivation & 1 & 0.4 & 1 & 1 \\
\hline defrost & 3 & 3.2 & 1 & 0 & deprive & 2 & 7.6 & 3 & 16 \\
\hline defroster & 0 & 0.2 & 0 & 0 & deprived & 0 & 0.2 & 8 & 0 \\
\hline deft & 1 & 2.0 & 2 & 2 & depth & 17 & 6.2 & 53 & 49 \\
\hline deftly & 0 & 0.4 & 0 & 3 & deputy & 2 & 2.8 & 17 & 13 \\
\hline deftness & 0 & 0.2 & 1 & 0 & other comp. & 3 & 10.8 & 0 & 0 \\
\hline defunct & 0 & 2.6 & 3 & 1 & & & & & \\
\hline defunction & 0 & 0.2 & 0 & 0 & $\mathrm{drab}$ & 1 & 8.8 & 5 & 4 \\
\hline defuse & 0 & 0.4 & 0 & 0 & drabble & 0 & 0.8 & 0 & 0 \\
\hline defy & 2 & 3.2 & 7 & 18 & drachma & 0 & 0.2 & 0 & 0 \\
\hline other comp. & 0 & 13.6 & - & - & dracula & 0 & 0.6 & 0 & 0 \\
\hline & & & & & draft & 3 & 5.4 & 24 & 30 \\
\hline depart & 9 & 6.6 & 7 & 50 & drag & 6 & 11.0 & 15 & 50 \\
\hline departing & 0 & 0.2 & 10 & 0 & dragnet & 0 & 0.4 & 2 & 0 \\
\hline department & 14 & 4.8 & 225 & 100 & dragon & 7 & 3.0 & 1 & 22 \\
\hline departure & 0 & 0.6 & 17 & 23 & dragoon & 0 & 0.2 & 0 & 4 \\
\hline depend & 26 & 7.4 & 45 & 50 & drain & 2 & 11.2 & 18 & 41 \\
\hline dependable & 1 & 0.6 & 8 & 3 & drainage & 1 & 0.2 & 13 & 9 \\
\hline dependant & 0 & 0.4 & 0 & 6 & drained & 0 & 0.4 & 7 & 0 \\
\hline dependence & 0 & 0.6 & 12 & 5 & draining & 0 & 0.2 & 3 & 0 \\
\hline dependent & 6 & 1.8 & 40 & 13 & drake & 0 & 3.0 & 2 & 8 \\
\hline depersonalize & 0 & 0.2 & 0 & 0 & dram & 1 & 0.6 & 1 & 1 \\
\hline depict & 1 & 4.8 & 3 & 7 & drama & 65 & 1.8 & 43 & 23 \\
\hline depilatory & 0 & 0.2 & 0 & 0 & dramamine & 0 & 0.4 & 0 & 0 \\
\hline deplane & 0 & 1.0 & 0 & 0 & dramatic & 1 & 1.6 & 63 & 20 \\
\hline deplete & 0 & 3.6 & 0 & 2 & dramatize & 1 & 0.4 & 3 & 2 \\
\hline deplorable & 0 & 0.4 & 2 & 4 & dramaturge & 0 & 0.2 & 0 & 0 \\
\hline deploration & 0 & 0.2 & 0 & 0 & drank & 0 & 3.2 & 19 & 23 \\
\hline deplore & 0 & 3.2 & 1 & 6 & drap & 0 & 0.4 & 0 & 0 \\
\hline deploy & 2 & 1.6 & 0 & 0 & drape & 6 & 12.4 & 0 & 6 \\
\hline deployment & 0 & 0.2 & 1 & 0 & drapery & 0 & 1.4 & 2 & 9 \\
\hline depolarize & 0 & 0.4 & 0 & 0 & drapes & 1 & 1.8 & 1 & 0 \\
\hline
\end{tabular}




\begin{tabular}{|c|c|c|c|c|c|c|c|c|c|}
\hline \multirow[b]{2}{*}{ Word } & \multicolumn{4}{|c|}{ Frequency } & \multirow[b]{2}{*}{ Word } & \multicolumn{4}{|c|}{ Frequency } \\
\hline & $\begin{array}{l}\text { 1st } \\
\text { Comp. }\end{array}$ & $\begin{array}{c}\text { 2nd-6th } \\
\text { Comp. }\end{array}$ & K\&F & $T \& L$ & & $\begin{array}{c}\text { 1st } \\
\text { Comp. }\end{array}$ & $\begin{array}{c}\text { 2nd-6th } \\
\text { Comp. }\end{array}$ & $K \& F$ & T\&L \\
\hline drastic & 2 & 6.8 & 11 & 5 & exposition & 0 & 1.2 & 6 & 10 \\
\hline drat & 1 & 2.2 & 0 & 0 & expository & 0 & 0.4 & 1 & 0 \\
\hline draught & 0 & 0.4 & 1 & 16 & expostulate & 0 & 0.2 & 0 & 1 \\
\hline draw & 2 & 8.8 & 56 & 100 & expound & 0 & 2.4 & 0 & 3 \\
\hline drawback & 0 & 0.2 & 2 & 3 & express & 1 & 3.2 & 42 & 100 \\
\hline drawer & 0 & 1.6 & 8 & 20 & expulsion & 0 & 0.4 & 4 & 3 \\
\hline drawers & 0 & 0.2 & 5 & 0 & expulsive & 0 & 0.2 & 0 & 0 \\
\hline drawl & 0 & 2.0 & 2 & 5 & expunge & 0 & 0.2 & 1 & 0 \\
\hline drawn & 0 & 1.4 & 70 & 49 & expurgate & 0 & 0.2 & 0 & 0 \\
\hline other comp. & 0 & 4.8 & - & - & other comp. & 0 & 7.2 & - & - \\
\hline & & & & & fila & 0 & 0.2 & 0 & 0 \\
\hline $\begin{array}{l}\text { expand } \\
\text { expatriate }\end{array}$ & 2 & 6.4 & 13 & 15 & filament & 2 & 7.2 & 1 & 7 \\
\hline expatriate & 0 & 1.2 & 0 & 0 & filamentary & 0 & 0.2 & 0 & 0 \\
\hline expect & 2 & 4.2 & 108 & 100 & filander & 1 & 0.0 & 0 & 0 \\
\hline expectant & 0 & 0.2 & 3 & 4 & filbert & 2 & 1.4 & 1 & 0 \\
\hline expectation & 0 & 0.2 & 11 & 14 & filberts & 0 & 0.2 & 2 & 0 \\
\hline expectorate & 0 & 0.4 & 0 & 0 & filch & 0 & 0.8 & 0 & 1 \\
\hline expedient & 0 & 1.0 & 7 & 7 & file & 18 & 12.0 & 81 & 43 \\
\hline expedite & 0 & 2.2 & 0 & 0 & filed & 0 & 0.4 & 33 & 0 \\
\hline expedition & 0 & 0.6 & 15 & 40 & files & 1 & 0.0 & 13 & 0 \\
\hline expel & 2 & 5.8 & 2 & 9 & filet & 1 & 1.6 & 0 & 0 \\
\hline expend & 1 & 2.6 & 1 & 8 & filial & 4 & 1.0 & 1 & 4 \\
\hline expendable & 0 & 0.4 & 1 & 0 & filiate & 1 & 0.0 & 0 & 0 \\
\hline expenditure & 0 & 1.2 & 11 & 16 & filiation & 0 & 0.2 & 0 & 0 \\
\hline expense & 0 & 0.8 & 50 & 50 & filibuster & 2 & 3.4 & 3 & 0 \\
\hline expensive & 1 & 1.2 & 44 & 28 & filigree & 0 & 1.2 & 1 & 0 \\
\hline experience & 10 & 7.4 & 276 & 100 & filing & 1 & 1.0 & 19 & 0 \\
\hline experiment & 32 & 4.4 & 63 & 50 & filipino & 0 & 0.6 & 2 & 7 \\
\hline expert & 4 & 6.0 & 30 & 39 & fill & 37 & 9.4 & 50 & 50 \\
\hline expertise & 0 & 1.4 & 3 & 0 & filled & 0 & 0.4 & 99 & 0 \\
\hline expiate & 0 & 0.4 & 0 & 1 & filler & 6 & 5.2 & 1 & 1 \\
\hline expire & 17 & 6.4 & 1 & 10 & fillet & 0 & 1.8 & 0 & 2 \\
\hline explain & 9 & 7.8 & 64 & 100 & filling & 5 & 2.2 & 36 & 50 \\
\hline explanation & 0 & 0.4 & 43 & 31 & fillings & 0 & 0.2 & 3 & 0 \\
\hline explete & 0 & 0.2 & 0 & 0 & filly & 2 & 2.6 & 9 & 0 \\
\hline explicable & 0 & 0.4 & 4 & 0 & film & 2 & 14.0 & 96 & 31 \\
\hline explicate & 0 & 1.8 & 0 & 0 & filmer & 0 & 0.2 & 0 & 0 \\
\hline explicit & 0 & 0.4 & 24 & 2 & filo & 0 & 0.4 & 0 & 0 \\
\hline explode & 1 & 1.8 & 6 & 9 & filter & 12 & 12.4 & 9 & 8 \\
\hline exploit & 0 & 0.4 & 9 & 12 & filth & 2 & 3.4 & 2 & 4 \\
\hline exploration & 0 & 0.2 & 25 & 13 & filthy & 0 & 2.8 & 7 & 6 \\
\hline explore & 4 & 3.2 & 12 & 19 & filtrate & 0 & 1.2 & 0 & 0 \\
\hline explosion & 0 & 0.4 & 15 & 15 & other comp. & 1 & 12.4 & - & - \\
\hline explosive & 0 & 0.6 & 17 & 9 & & & & & \\
\hline expo & 0 & 0.2 & 0 & 0 & float & 4 & 12.6 & 3 & 50 \\
\hline exponent & 4 & 3.2 & 0 & 2 & flock & 0 & 7.4 & 10 & 44 \\
\hline exponential & 0 & 2.2 & 1 & 0 & flog & 0 & 3.6 & 1 & 2 \\
\hline export & 3 & 5.0 & 10 & 24 & flogging & 0 & 0.4 & 0 & 0 \\
\hline expose & 7 & 3.6 & 8 & 32 & flood & 2 & 4.0 & 19 & 50 \\
\hline exposes & 0 & 0.2 & 2 & 0 & floor & 4 & 7.8 & 158 & 100 \\
\hline
\end{tabular}




\begin{tabular}{|c|c|c|c|c|c|c|c|c|c|}
\hline \multirow[b]{2}{*}{ Word } & \multicolumn{4}{|c|}{ Frequency } & \multirow[b]{2}{*}{ Word } & \multicolumn{4}{|c|}{ Frequency } \\
\hline & $\begin{array}{c}\text { 1st } \\
\text { Comp. }\end{array}$ & $\begin{array}{c}\text { 2nd-6th } \\
\text { Comp. }\end{array}$ & K\&F & T\&L & & $\begin{array}{c}\text { 1st } \\
\text { Comp. }\end{array}$ & $\begin{array}{c}\text { 2nd-6th } \\
\text { Comp. }\end{array}$ & $K \& F$ & $T \& L$ \\
\hline floozie & 0 & 0.2 & 0 & 0 & forensic & 0 & 0.6 & 7 & 0 \\
\hline floozy & 0 & 1.0 & 0 & 0 & foreplay. & 0 & 1.0 & 0 & 0 \\
\hline flop & 2 & 10.6 & 1 & 5 & forerunner & 1 & 0.6 & 7 & 1 \\
\hline flora & 1 & 0.2 & 1 & 7 & foresee & 0 & 0.6 & 3 & 8 \\
\hline floral & 1 & 0.6 & 3 & 2 & forest & 6 & 4.4 & 66 & 100 \\
\hline florescent & 0 & 1.6 & 0 & 0 & forestation & 0 & 0.2 & 0 & 0 \\
\hline florist & 1 & 2.6 & 1 & 2 & foretell & 0 & 0.4 & 1 & 2 \\
\hline floss & 0 & 5.0 & 0 & 3 & foretold & 0 & 0.8 & 0 & 5 \\
\hline flotation & 0 & 0.4 & 0 & 0 & forever & 1 & 3.8 & 39 & 50 \\
\hline flotilla & 0 & 0.2 & 1 & 1 & forewarn & 0 & 0.2 & 0 & 1 \\
\hline flotsam & 0 & 1.0 & 0 & 0 & forfeit & 1 & 1.2 & 3 & 9 \\
\hline flounce & 0 & 0.2 & 0 & 2 & forgave & 0 & 0.4 & 2 & 3 \\
\hline flouncy & 0 & 0.2 & 0 & 0 & forge & 1 & 4.4 & 10 & 17 \\
\hline flounder & 0 & 4.2 & 1 & 6 & forgery & 0 & 0.2 & 1 & 3 \\
\hline flour & 0 & 6.4 & 8 & 50 & forget & 6 & 5.0 & 54 & 100 \\
\hline flourish & 0 & 1.8 & 5 & 25 & forgive & 3 & 1.4 & 24 & 40 \\
\hline flout & 0 & 0.8 & 0 & 1 & forgiven & 0 & 0.2 & 6 & 7 \\
\hline flow & 56 & 6.0 & 67 & 100 & forgo & 1 & 0.2 & 1 & 0 \\
\hline flower & 27 & 10.8 & 23 & 100 & forgot & 0 & 0.4 & 18 & 50 \\
\hline flowing & 2 & 0.0 & 17 & 0 & forgotten & 1 & 0.2 & 38 & 50 \\
\hline flown & 0 & 4.6 & 4 & 8 & fork & 0 & 7.6 & 14 & 31 \\
\hline \multirow[t]{2}{*}{ other comp. } & 0 & 4.0 & - & - & forlorn & 0 & 3.0 & 3 & 10 \\
\hline & & & & & form & 14 & 6.4 & 370 & 100 \\
\hline forage & 1 & 0.6 & 3 & 5 & formal & 2 & 2.2 & 48 & 22 \\
\hline foramen & 0 & 0.2 & 0 & 0 & formally & 0 & 0.2 & 18 & 7 \\
\hline foray & 0 & 0.2 & 1 & 1 & format & 1 & 1.0 & 9 & 0 \\
\hline forbade & 0 & 0.2 & 1 & 6 & formation & 0 & 0.4 & 37 & 19 \\
\hline forbid & 1 & 3.0 & 4 & 29 & formative & 0 & 0.2 & 2 & 0 \\
\hline forbidden & 0 & 0.6 & 15 & 14 & former & 2 & 1.6 & 131 & 100 \\
\hline forbode & 0 & 0.4 & 0 & 0 & formica & 0 & 0.2 & 0 & 0 \\
\hline forboding & 0 & 0.4 & 0 & 0 & formidable & 0 & 0.4 & 17 & 12 \\
\hline force & 1 & 3.4 & 230 & 100 & forming & 0 & 0.4 & 21 & 0 \\
\hline forced & 0 & 0.2 & 81 & 0 & formless & 0 & 0.2 & 0 & 0 \\
\hline forceps & 0 & 0.2 & 0 & 1 & formula & 5 & 1.4 & 59 & 11 \\
\hline forclose & 0 & 0.2 & 0 & 0 & formulate & 0 & 1.0 & 9 & 6 \\
\hline ford & 0 & 1.0 & 24 & 32 & fornicate & 0 & 1.8 & 0 & 0 \\
\hline fore & 7 & 1.6 & 7 & 11 & fornication & 1 & 0.6 & 0 & 0 \\
\hline forearm & 0 & 0.2 & 3 & 2 & forsake & 0 & 0.4 & 1 & 7 \\
\hline foreboding & 0 & 0.2 & 4 & 3 & forsaken & 0 & 0.2 & 2 & 6 \\
\hline forecast & 0 & 0.6 & 10 & 6 & fort & 13 & 4.8 & 55 & 43 \\
\hline foreclose & 0 & 0.2 & 0 & 1 & forth & 1 & 15.6 & 71 & 100 \\
\hline foreclosure & 0 & 0.2 & 0 & 0 & fortification & 0 & 0.2 & 0 & 7 \\
\hline forefinger & 0 & 0.2 & 6 & 4 & fortify & 0 & 2.6 & 2 & 9 \\
\hline forego & 0 & 0.2 & 3 & 3 & fortitude & 1 & 1.0 & 3 & 5 \\
\hline foregone & 1 & 0.2 & 1 & 3 & fortnight & 0 & 0.4 & 1 & 11 \\
\hline foreground & 0 & 0.2 & 2 & 3 & fortran & 0 & 0.6 & 0 & 0 \\
\hline foreign & 2 & 1.8 & 158 & 100 & fortress & 0 & 1.2 & 6 & 18 \\
\hline foreigner & 1 & 0.8 & 4 & 27 & fortuitous & 0 & 0.4 & 0 & 1 \\
\hline foreman & 1 & 0.8 & 4 & 7 & fortunate & 1 & 1.0 & 22 & 23 \\
\hline foremost & 2 & 1.6 & 12 & 17 & fortunately & 0 & 0.2 & 20 & 19 \\
\hline
\end{tabular}




\begin{tabular}{|c|c|c|c|c|c|c|c|c|c|}
\hline \multirow[b]{2}{*}{ Word } & \multicolumn{4}{|c|}{ Frequency } & \multirow[b]{2}{*}{ Word } & \multicolumn{4}{|c|}{ Frequency } \\
\hline & $\begin{array}{c}\text { 1st } \\
\text { Comp. }\end{array}$ & $\begin{array}{c}\text { 2nd-6th } \\
\text { Comp. }\end{array}$ & $K \& F$ & $=T \& L$ & & $\begin{array}{c}\text { 1st } \\
\text { Comp. }\end{array}$ & $\begin{array}{c}\text { 2nd-6th } \\
\text { Comp. }\end{array}$ & $K \& F$ & $=T \& L$ \\
\hline fortune & 7 & 4.8 & 25 & 50 & garage & 39 & 8.0 & 21 & 14 \\
\hline forty & 0 & 1.4 & 36 & 50 & garb & 1 & 6.4 & 3 & 7 \\
\hline forum & 0 & 1.6 & 10 & 5 & garbage & 18 & 11.4 & 7 & 4 \\
\hline forward & 11 & 1.4 & 115 & 100 & garbanzo & 0 & 1.0 & 0 & 0 \\
\hline other comp. & 3 & 2.2 & - & - & garble & 0 & 2.2 & 0 & 0 \\
\hline & & & & & garbled & 0 & 0.2 & 1 & 0 \\
\hline fracas & 0 & 1.0 & 0 & 0 & garcon & 0 & 0.6 & 0 & 0 \\
\hline frack & 0 & 0.6 & 0 & 0 & garden & 7 & 9.8 & 60 & 100 \\
\hline fraction & 0 & $1 \cdot 6$ & 23 & 12 & gardener & 0 & 0.6 & 4 & 0 \\
\hline fracture & 2 & 2.4 & 1 & 7 & gardenia & 0 & 0.8 & 1 & 1 \\
\hline fragile & 10 & 7.2 & 10 & 7 & garfish & 1 & 0.0 & 0 & 0 \\
\hline fragility & 0 & 0.2 & 0 & 0 & gargantuan & 1 & 2.6 & 1 & 0 \\
\hline fragment & 6 & 5.6 & 6 & 24 & gargle & 1 & 6.2 & 2 & 0 \\
\hline fragrance & 2 & 2.6 & 6 & 12 & gargoyle & 0 & 2.8 & 0 & 0 \\
\hline fragrant & 2 & 0.4 & 3 & 14 & garish & 3 & 3.6 & 1 & 1 \\
\hline fraid & 0 & 0.2 & 0 & 0 & garland & 3 & 1.2 & 9 & 11 \\
\hline frail & 6 & 11.8 & 8 & 16 & garlic & 0 & 3.0 & 4 & 3 \\
\hline frailty & 0 & 0.8 & 0 & 3 & garment & 5 & 6.0 & 6 & 40 \\
\hline framable & 0 & 0.2 & 0 & 0 & garn & 0 & 0.2 & 0 & 0 \\
\hline frame & 38 & 8.6 & 74 & 50 & garner & 0 & 1.0 & 1 & 4 \\
\hline framed & 1 & 0.0 & 14 & 0 & garnet & 1 & 3.0 & 1 & 2 \\
\hline franc & 0 & 0.2 & 1 & 14 & garnish & 10 & 8.2 & 0 & 11 \\
\hline france & 0 & 0.8 & 74 & 100 & garnished & 0 & 0.2 & 0 & 0 \\
\hline franchise & 0 & 1.0 & 5 & 4 & garret & 0 & 0.6 & 0 & 7 \\
\hline frank & 5 & 3.4 & 68 & 70 & garrison & 1 & 1.8 & 5 & 19 \\
\hline frankfurter & 1 & 0.6 & 17 & 1 & garrot & 0 & 0.4 & 0 & 0 \\
\hline frankly & 0 & 1.8 & 13 & 29 & garrulous & 1 & 1.0 & 1 & 1 \\
\hline frankness & 0 & 0.6 & 4 & 5 & garter & 7 & 7.6 & 2 & 5 \\
\hline frantic & 3 & 6.4 & 11 & 12 & garth & 0 & 0.2 & 14 & 0 \\
\hline frantically & 0 & 0.2 & 8 & 6 & other comp. & 1 & 8.8 & - & - \\
\hline frap & 0 & 0.6 & 0 & 0 & & & & & \\
\hline frappe & 0 & 1.8 & 0 & 0 & gender & 10 & 12.0 & 2 & 1 \\
\hline frase & 0 & 0.4 & 0 & 0 & gene & 6 & 5.4 & 9 & 0 \\
\hline frat & 1 & 0.4 & 0 & 0 & genera & 0 & 0.4 & 1 & 0 \\
\hline frate & 0 & 0.8 & 0 & 0 & general & 40 & 7.4 & 497 & 100 \\
\hline fraternal & 0 & 1.0 & 0 & 4 & generalize & 1 & 0.4 & 5 & 2 \\
\hline fraternity & 19 & 11.2 & 6 & 8 & generally & 0 & 0.4 & 132 & 50 \\
\hline fraternization & 0 & 0.2 & 0 & 0 & generate & 5 & 5.4 & 7 & 7 \\
\hline fraternize & 1 & 2.2 & 1 & 0 & generation & 2 & 1.0 & 55 & 48 \\
\hline fratricide & 0 & 0.4 & 0 & 0 & generator & 0 & 1.4 & 14 & 2 \\
\hline frau & 0 & 0.2 & 1 & 4 & generic & 3 & 3.0 & 0 & 0 \\
\hline fraud & 2 & 2.6 & 8 & 10 & generous & 5 & 8.2 & 25 & 40 \\
\hline fraudulent & 0 & 0.2 & 0 & 2 & genes & 0 & 1.6 & 1 & 0 \\
\hline fraught & 0 & 1.0 & 0 & 4 & genesis & 5 & 2.4 & 4 & 2 \\
\hline fraulein & 0 & 0.4 & 0 & 1 & genetic & 1 & 1.4 & 5 & 0 \\
\hline fray & 0 & 6.2 & 1 & 7 & genetics & 1 & 2.6 & 0 & 0 \\
\hline frayed & 0 & 1.4 & 3 & 0 & genial & 0 & 0.8 & 5 & 9 \\
\hline frazzle & 0 & 1.6 & 0 & 0 & genie & 0 & 0.2 & 1 & 1 \\
\hline frazzled & 1 & 0.0 & 1 & 0 & genital & 0 & 2.4 & 0 & 0 \\
\hline other comp. & 0 & 9.2 & - & - & genitalia & 0 & 0.4 & 0 & 0 \\
\hline
\end{tabular}




\begin{tabular}{|c|c|c|c|c|c|c|c|c|c|}
\hline \multirow[b]{2}{*}{ Word } & \multicolumn{4}{|c|}{ Frequency } & \multirow[b]{2}{*}{ Word } & \multicolumn{4}{|c|}{ Frequency } \\
\hline & $\begin{array}{c}\text { Ist } \\
\text { Comp. }\end{array}$ & $\begin{array}{c}\text { 2nd-6th } \\
\text { Comp. }\end{array}$ & $K \& F$ & T\&L & & $\begin{array}{c}\text { 1st } \\
\text { Comp. }\end{array}$ & $\begin{array}{c}\text { 2nd-6th } \\
\text { Comp. }\end{array}$ & $\mathbf{K} \& \mathbf{F}$ & T\&L \\
\hline genitals & 0 & 0.8 & 0 & 0 & grant & 1 & 2.0 & 47 & 100 \\
\hline genius & 0 & 1.8 & 23 & 30 & granular & 0 & 0.2 & 3 & 0 \\
\hline genocide & 1 & 3.6 & 0 & 0 & granule & 0 & 0.2 & 0 & 1 \\
\hline genome & 0 & 0.4 & 0 & 0 & grape & 12 & 7.6 & 3 & 34 \\
\hline genotype & 0 & 0.4 & 0 & 0 & grapefruit & 0 & 0.2 & 3 & 2 \\
\hline genre & 0 & 0.8 & 2 & 1 & grapes & 0 & 0.2 & 7 & 0 \\
\hline gent & 0 & 1.0 & 0 & 1 & graph & 17 & 2.2 & 17 & 0 \\
\hline genteel & 0 & 0.4 & 4 & 3 & graphic & 3 & 0.8 & 6 & 3 \\
\hline gentile & 2 & 3.0 & 13 & 1 & graphite & 0 & 0.2 & 5 & 4 \\
\hline gentle & 12 & 11.8 & 27 & 100 & grapple & 1 & 3.2 & 1 & 3 \\
\hline gentleman & 4 & 5.4 & 28 & 100 & grappling & 0 & 0.4 & 4 & 0 \\
\hline gentlemen & 0 & 2.4 & 21 & 0 & grasp & 2 & 2.6 & 17 & 36 \\
\hline gent1y & 0 & 0.2 & 31 & 46 & grass & 6 & 6.6 & 53 & 100 \\
\hline gentry & 0 & 0.8 & 1 & 5 & grate & 1 & 6.4 & 3 & 13 \\
\hline genuflect & 0 & 0.8 & 0 & 0 & grateful & 3 & 1.6 & 25 & 37 \\
\hline genuine & 2 & 3.8 & 34 & 19 & gratefully & 0 & 0.2 & 3 & 5 \\
\hline genus & 0 & 0.2 & 2 & 4 & gratification & 0 & 0.2 & 4 & 4 \\
\hline other comp. & 0 & 5.4 & - & - & gratify & 1 & 1.4 & 1 & 12 \\
\hline & & & & & grating & 0 & 0.4 & 1 & 7 \\
\hline grab & 1 & 5.6 & 16 & 18 & gratis & 0 & 0.4 & 1 & 2 \\
\hline grace & 1 & 2.2 & 40 & 50 & gratitude & 0 & 3.6 & 9 & 22 \\
\hline graceful & 0 & 0.8 & 10 & 19 & gratuitous & 0 & 0.4 & 3 & 1 \\
\hline gracious & 3 & 2.6 & 9 & 24 & gratuity & 0 & 0.2 & 0 & 0 \\
\hline $\operatorname{grad}$ & 1 & 0.0 & 2 & 1 & grave & 0 & 1.0 & 33 & 50 \\
\hline grade & 26 & 3.6 & 35 & 44 & gravel & 1 & 2.0 & 9 & 15 \\
\hline grades & 0 & 0.2 & 23 & 0 & gravettian & 0 & 0.2 & 0 & 0 \\
\hline gradient & 0 & 2.0 & 14 & 0 & gravity & 0 & 0.2 & 7 & 14 \\
\hline gradual & 0 & 2.2 & 16 & 13 & gravy & 1 & 0.0 & 4 & 8 \\
\hline gradually & 0 & 0.2 & 51 & 50 & gray & 1 & 2.6 & 80 & 100 \\
\hline graduate & 1 & 4.4 & 30 & 28 & graze & 0 & 1.6 & 1 & 16 \\
\hline graduation & 0 & 0.4 & 11 & 5 & other comp. & 1 & 1.4 & - & - \\
\hline graf & 0 & 0.2 & 0 & 0 & & & & & \\
\hline graffiti & 1 & 0.0 & 1 & 0 & groan & 2 & 9.8 & 1 & 34 \\
\hline graft & 1 & 1.4 & 1 & 8 & groat & 0 & 0.4 & 1 & 1 \\
\hline graham & 1 & 0.0 & 15 & 7 & groats & 0 & 0.2 & 0 & 0 \\
\hline grail & 0 & $2 \cdot 6$ & 2 & 2 & grocer & 1 & 0.2 & 1 & 11 \\
\hline grain & 2 & 5.4 & 27 & 50 & groceries & 1 & 0.4 & 2 & 0 \\
\hline grainery & 0 & 0.2 & 0 & 0 & grocery & 4 & 2.6 & 9 & 11 \\
\hline gram & 2 & 5.0 & 10 & 1 & grog & 0 & 1.8 & 0 & 0 \\
\hline grammar & 5 & 1.8 & 4 & 10 & groggy & 0 & 3.0 & 1 & 0 \\
\hline grand & 4 & 6.2 & 48 & 50 & groin & 0 & 2.6 & 4 & 0 \\
\hline grandeur & 0 & 0.2 & 6 & 9 & grommet & 0 & 1.4 & 0 & 0 \\
\hline grand father & 0 & 0.2 & 12 & 36 & groom & 2 & 2.4 & 5 & 16 \\
\hline grandma & 0 & 0.4 & 13 & 10 & groove & 0 & 1.4 & 2 & 8 \\
\hline grandmother & 0 & 0.2 & 9 & 48 & groovy & 0 & 0.2 & 0 & 0 \\
\hline grandpa & 0 & 0.4 & 0 & 9 & grope & 3 & 13.6 & 1 & 10 \\
\hline grand parent & 0 & 0.2 & 0 & 1 & groping & 0 & 0.4 & 5 & 0 \\
\hline grange & 0 & 0.4 & 0 & 5 & gross & 7 & 10.6 & 66 & 15 \\
\hline granite & 0 & 0.2 & 3 & 15 & grotesque & 2 & 3.0 & 9 & 6 \\
\hline granola & 0 & 0.6 & 0 & 0 & grotto & 0 & 1.2 & 0 & 3 \\
\hline
\end{tabular}




\begin{tabular}{|c|c|c|c|c|c|c|c|c|c|}
\hline \multirow[b]{2}{*}{ Word } & \multicolumn{4}{|c|}{ Frequency } & \multirow[b]{2}{*}{ Word } & \multicolumn{4}{|c|}{ Frequency } \\
\hline & $\begin{array}{l}\text { 1st } \\
\text { Comp. }\end{array}$ & $\begin{array}{l}\text { 2nd-6th } \\
\text { Comp. }\end{array}$ & K\&F & T\&L & & $\begin{array}{l}\text { 1st } \\
\text { Comp. }\end{array}$ & $\begin{array}{c}\text { 2nd-6th } \\
\text { Comp. }\end{array}$ & K\&F & T\&L \\
\hline grouch & 1 & 1.6 & 0 & 1 & harry & 0 & 0.4 & 35 & 56 \\
\hline ground & 6 & 6.6 & 186 & 100 & harsh & 0 & 3.8 & 12 & 17 \\
\hline grounded & 0 & 0.4 & 6 & 0 & harshly & 0 & 0.2 & 5 & 5 \\
\hline group & 11 & 5.6 & 390 & 100 & hart & 4 & 0.6 & 13 & 7 \\
\hline grouse & 0 & 0.8 & 0 & 8 & harvest & 2 & 1.8 & 12 & 48 \\
\hline grout & 0 & 2.6 & 0 & 0 & other comp. & 0 & 6.4 & - & - \\
\hline grove & 1 & 3.0 & 14 & 31 & & & & & \\
\hline grove1 & 0 & 2.6 & 1 & 2 & leach & 6 & 1.8 & 0 & 1 \\
\hline groveling & 0 & 0.2 & 1 & 0 & lead & 12 & 10.6 & 129 & 100 \\
\hline grow & 54 & 5.8 & 63 & 100 & leader & 3 & 1.4 & 74 & 100 \\
\hline grower & 1 & 0.0 & 1 & 3 & leaf & 24 & 8.6 & 12 & 27 \\
\hline growing & 0 & 0.2 & 108 & 0 & leaflet & 0 & 0.4 & 1 & 7 \\
\hline grow1 & 0 & 5.6 & 4 & 23 & league & 0 & 2.0 & 69 & 50 \\
\hline growling & 0 & 0.2 & 1 & 0 & leak & 8 & 12.2 & 2 & 8 \\
\hline grown & 1 & 2.8 & 43 & 50 & leakage & 0 & 0.2 & 1 & 1 \\
\hline growth & 3 & 3.2 & 155 & 50 & lean & 11 & 13.4 & 20 & 50 \\
\hline \multirow[t]{2}{*}{ other comp. } & 0 & 3.2 & - & - & leaning & 0 & 0.2 & 15 & 0 \\
\hline & & & & & leap & 3 & 11.6 & 14 & 50 \\
\hline harangue & 3 & 0.4 & 0 & 2 & lear & 1 & 3.0 & 4 & 2 \\
\hline harass & 8 & 5.2 & 1 & 7 & learn & 3 & 6.8 & 84 & 100 \\
\hline harbinger & 1 & 0.4 & 0 & 1 & learned & 0 & 0.2 & 117 & 16 \\
\hline harbor & 6 & 4.4 & 37 & 50 & learning & 0 & 0.4 & 60 & 27 \\
\hline hard & 17 & 11.2 & 202 & 100 & leary & 0 & 1.0 & 1 & 0 \\
\hline harden & 0 & 0.8 & 1 & 19 & lease & 4 & 4.8 & 10 & 14 \\
\hline hardly & 0 & 1.4 & 106 & 50 & leash & 2 & 0.8 & 3 & 3 \\
\hline hardy & 1 & 1.2 & 42 & 15 & least & 0 & 4.6 & 343 & 100 \\
\hline hare & 18 & 7.0 & 1 & 18 & leat & 0 & 0.2 & 0 & 0 \\
\hline harem & 5 & 2.0 & 2 & 2 & leather & 1 & 1.6 & 24 & 50 \\
\hline haring & 1 & 0.0 & 0 & 0 & leave & 18 & 6.4 & 205 & 100 \\
\hline hark & 2 & 10.2 & 3 & 14 & leavening & 0 & 0.2 & 1 & 0 \\
\hline harken & 0 & 1.0 & 0 & 3 & leaves & 2 & 0.2 & 49 & 0 \\
\hline harlem & 0 & 0.2 & 14 & 4 & other comp. & 2 & 7.2 & - & - \\
\hline harlequin & 1 & 0.4 & 0 & 1 & & & & & \\
\hline harlot & 2 & 2.2 & 0 & 3 & maraschino & 0 & 0.2 & 0 & 1 . \\
\hline harm & 2 & 9.0 & 25 & 50 & marauder & 0 & 0.2 & 0 & 2 \\
\hline harmful & 0 & 1.6 & 4 & 7 & marble & 0 & 4.6 & 21 & 38 \\
\hline harmless & 0 & 0.2 & 5 & 15 & marbles & 0 & 0.8 & 3 & 0 \\
\hline harmonica & 0 & 1.0 & 0 & 2 & $\operatorname{marc}$ & 0 & 0.2 & 2 & 6 \\
\hline harmonious & 0 & 0.2 & 5 & 6 & march & 41 & 2.6 & 120 & 150 \\
\hline harmonize & 0 & 0.4 & 0 & 4 & marched & 0 & 0.2 & 9 & 0 \\
\hline harmony & 3 & 3.2 & 33 & 23 & marching & 1 & 0.2 & 15 & 0 \\
\hline harness & 2 & 7.4 & 10 & 29 & mardi gras & 0 & 0.4 & 0 & 0 \\
\hline harold & 0 & 0.4 & 32 & 12 & mare & 5 & 6.8 & 16 & 14 \\
\hline harp & 19 & 11.2 & 1 & 20 & margarine & 0 & 2.2 & 0 & 0 \\
\hline harpist & 0 & 0.2 & 0 & 0 & margin & 0 & 1.6 & 10 & 19 \\
\hline harpoon & 1 & 1.2 & 0 & 1 & marginal & 0 & 0.6 & 25 & 8 \\
\hline harpsichord & 0 & 0.2 & 1 & 1 & marigold & 0 & 1.2 & 0 & 3 \\
\hline harried & 1 & 0.6 & 1 & 0 & marijuana & 0 & 0.2 & 10 & 0 \\
\hline harrow & 0 & 0.4 & 2 & 5 & marina & 0 & 0.2 & 10 & 0 \\
\hline harrowing & 1 & 1.6 & 2 & 0 & marinate & 0 & 1.4 & 0 & 1 \\
\hline
\end{tabular}




\begin{tabular}{|c|c|c|c|c|c|c|c|c|c|}
\hline \multirow[b]{2}{*}{ Word } & \multicolumn{4}{|c|}{ Frequency } & \multirow[b]{2}{*}{ Word } & \multicolumn{4}{|c|}{ Frequency } \\
\hline & $\begin{array}{l}\text { 1st } \\
\text { Comp. }\end{array}$ & $\begin{array}{c}\text { 2nd-6th } \\
\text { Comp. }\end{array}$ & $K \& F$ & T\&L & & $\begin{array}{c}\text { 1st } \\
\text { Comp. }\end{array}$ & $\begin{array}{c}\text { 2nd-6th } \\
\text { Comp. }\end{array}$ & K\&f & E T\&L \\
\hline marine & 1 & 2.0 & 55 & 17 & moratorium & 0 & 0.8 & 1 & 0 \\
\hline mariner & 0 & 0.2 & 1 & 10 & moray & 0 & 0.2 & 0 & 0 \\
\hline marionette & 0 & 0.2 & 0 & 0 & morbid & 8 & 10.4 & 1 & 3 \\
\hline marital & 0 & 0.6 & 10 & 1 & mordant & 0 & 0.2 & 0 & 0 \\
\hline maritime & 0 & 0.6 & 4 & 6 & more & 29 & 11.6 & 2216 & 100 \\
\hline mark & 8 & 10.8 & 83 & 150 & moreover & 0 & 1.0 & 88 & 36 \\
\hline marked & 0 & 0.2 & 85 & 0 & morgue & 3 & $4 \cdot 6$ & 1 & 2 \\
\hline marker & 0 & 2.0 & 5 & 2 & moribund & 0 & 1.0 & 0 & 0 \\
\hline market & 9 & 9.0 & 155 & 100 & mormon & 4 & 2.0 & 2 & 2 \\
\hline marketing & 0 & 0.2 & 43 & 0 & morn & 1 & 1.8 & 0 & 15 \\
\hline marking & 0 & 0.4 & 11 & 0 & mornful & 0 & 0.2 & 0 & 0 \\
\hline marlin & 0 & 0.8 & 2 & 0 & morning & 14 & 7.4 & 211 & 100 \\
\hline marm & 0 & 0.2 & 0 & 0 & mornings & 1 & 0.0 & 10 & 0 \\
\hline marmalade & 0 & 2.0 & 1 & 2 & moron & 7 & 5.4 & 0 & 0 \\
\hline marmoset & 0 & 0.4 & 0 & 0 & morose & 1 & 4.2 & 2 & 3 \\
\hline maroon & 0 & 1.4 & 3 & 2 & morpheme & 3 & 1.4 & 0 & 0 \\
\hline marque & 0 & 0.4 & 0 & 0 & morphine & 1 & 3.0 & 1 & 1 \\
\hline marquee & 0 & 0.2 & 0 & 0 & morphology & 1 & 0.2 & 2 & 0 \\
\hline marred & 0 & 1.6 & 4 & 0 & morphosis & 0 & 0.2 & 0 & 0 \\
\hline marriage & 7 & 4.6 & 95 & 50 & morrow & 1 & 1.0 & 2 & 7 \\
\hline married & 1 & 0.8 & 105 & 50 & morse & 0 & 2.6 & 29 & 7 \\
\hline marrow & 0 & 1.0 & 5 & 5 & morsel & 1 & 1.8 & 3 & 8 \\
\hline marry & 9 & 6.2 & 18 & 100 & mort & 0 & 0.2 & 2 & 0 \\
\hline mars & 4 & 1.4 & 21 & 15 & mortal & 4 & 6.8 & 10 & 35 \\
\hline marseilles & 0 & 0.2 & 1 & 1 & mortality & 0 & 0.2 & 9 & 8 \\
\hline marsh & 6 & 2.4 & 4 & 16 & mortalize & 0 & 0.2 & 0 & 0 \\
\hline marshal & 0 & 0.8 & 26 & 18 & mortar & 3 & 4.4 & 11 & 8 \\
\hline marshall & 0 & 0.2 & 27 & 5 & mortgage & 5 & 3.4 & 17 & 18 \\
\hline marshmallow & 0 & 0.4 & 0 & 1 & mortician & 2 & 2.8 & 0 & 0 \\
\hline marshmallows & 0 & 0.2 & 1 & 0 & mortified & 0 & 0.6 & 0 & 0 \\
\hline marsupial & 0 & 1.6 & 0 & 0 & mortify & 2 & 3.6 & 0 & 5 \\
\hline $\operatorname{mart}$ & 2 & 2.8 & 2 & 5 & mortuary & 0 & 3.2 & 0 & 0 \\
\hline martial & 1 & 1.0 & 0 & 7 & other comp. & 0 & 5.2 & - & - \\
\hline martian & 3 & 3.2 & 5 & 1 & & & & & \\
\hline martini & 0 & 0.8 & 6 & 0 & parable & 0 & 0.4 & 3 & 2 \\
\hline martyr & 0 & 4.4 & 8 & 10 & parabola & 0 & 0.4 & 0 & 1 \\
\hline marvel & 0 & 1.6 & 6 & 25 & parabolic & 0 & 0.2 & 0 & 0 \\
\hline marvelous & 2 & 4.0 & 11 & 33 & parachute & 1 & 1.6 & 1 & 5 \\
\hline marxism & 0 & 0.2 & 0 & 0 & parade & 0 & 1.6 & 25 & 16 \\
\hline marxist & 0 & 0.2 & 3 & 0 & paradigm & 0 & 0.2 & 6 & 0 \\
\hline marzipan & 0 & 0.4 & 0 & 0 & paradise & 0 & 0.4 & 12 & 29 \\
\hline other comp. & 0 & 4.4 & - & - & paradox & 0 & 0.4 & 9 & 3 \\
\hline & & & & & paraffin & 0 & 0.6 & 0 & 3 \\
\hline mora & 0 & 0.2 & 0 & 0 & paragraph & 7 & 1.4 & 12 & 12 \\
\hline moral & 8 & 4.4 & 142 & 50 & parakeet & 1 & 0.4 & 0 & 0 \\
\hline morale & 0 & 1.2 & 17 & 0 & parallel & 0 & 2.4 & 40 & 23 \\
\hline morality & 0 & 0.4 & 29 & 7 & paramecium & 0 & 0.4 & 0 & 0 \\
\hline morally & 0 & 0.2 & 7 & 3 & paramedic & 0 & 0.4 & 0 & 0 \\
\hline morals & 1 & 0.2 & 7 & 0 & parameter & 2 & 0.4 & 7 & 0 \\
\hline morass & 0 & 0.2 & 1 & 2 & paramount & 1 & 0.4 & 9 & 5 \\
\hline
\end{tabular}




\begin{tabular}{|c|c|c|c|c|c|c|c|c|c|}
\hline \multirow[b]{2}{*}{ Word } & \multicolumn{4}{|c|}{ Frequency } & \multirow[b]{2}{*}{ Word } & \multicolumn{4}{|c|}{ Frequency } \\
\hline & $\begin{array}{l}\text { 1st } \\
\text { Comp. }\end{array}$ & $\begin{array}{c}\text { 2nd-6th } \\
\text { Comp. }\end{array}$ & $K \& F$ & $=T \& L$ & & $\begin{array}{c}\text { 1st } \\
\text { Comp. }\end{array}$ & $\begin{array}{l}\text { 2nd-6th } \\
\text { Comp. }\end{array}$ & $K \& F$ & F T\&I \\
\hline paranoid & 0 & 0.2 & 2 & 0 & participant & 0 & 0.2 & 4 & 1 \\
\hline paraphernalia & 0 & 0.4 & 1 & 1 & participate & 0 & 2.6 & 22 & 8 \\
\hline paraphrase & 1 & 0.8 & 2 & 0 & participle & 0 & 0.4 & 0 & 1 \\
\hline paraplegic & 0 & 0.2 & 0 & 0 & particle & 2 & 1.8 & 21 & 17 \\
\hline parasite & 1 & 0.4 & 1 & 5 & particular & 0 & 1.4 & 179 & 50 \\
\hline parasitic & 1 & 0.0 & 2 & 1 & parting & 0 & 0.2 & 4 & 6 \\
\hline parasol & 0 & 0.4 & 3 & 2 & partition & 2 & 1.6 & 6 & 10 \\
\hline paratrooper & 0 & 0.2 & 0 & 0 & partner & 1 & 2.4 & 32 & 32 \\
\hline parboiled & 0 & 0.2 & 1 & 0 & partridge & 4 & 0.6 & 0 & 12 \\
\hline parcel & 0 & 2.2 & 1 & 23 & party & 9 & 5.6 & 216 & 100 \\
\hline parch & 0 & 0.6 & 0 & 6 & other comp. & 2 & 3.4 & - & - \\
\hline parched & 0 & 0.8 & 2 & 0 & & & & & \\
\hline parcheesi & 0 & 0.2 & 0 & 0 & relapse & 0 & 2.8 & 0 & 3 \\
\hline parchment & 1 & 0.4 & 1 & 8 & relate & 11 & 8.4 & 7 & 33 \\
\hline pardon & 1 & 6.4 & 8 & 36 & relation & 1 & 1.4 & 63 & 50 \\
\hline pare & 9 & 2.8 & 2 & 5 & relationship & 0 & 1.0 & 88 & 16 \\
\hline pared & 0 & 0.2 & 0 & 0 & relative & 15 & 6.0 & 46 & 40 \\
\hline parent & 7 & 3.0 & 15 & 50 & relatively & 0 & 0.2 & 85 & 13 \\
\hline parenthesis & 0 & 0.2 & 0 & 0 & relativity & 0 & 0.2 & 3 & 0 \\
\hline parents & 0 & 0.6 & 91 & 0 & relax & 0 & 4.4 & 19 & 17 \\
\hline parfait & 0 & 0.6 & 0 & 0 & relay & 3 & 2.8 & 2 & 3 \\
\hline paring & 1 & 0.2 & 0 & 1 & relearn & 0 & 1.8 & 0 & 0 \\
\hline paris & 0 & 0.4 & 67 & 100 & release & 5 & 3.4 & 37 & 37 \\
\hline parish & 1 & 2.2 & 11 & 11 & relegate & 0 & 0.4 & 0 & 1 \\
\hline parity & 0 & 0.6 & 0 & 0 & relent & 0 & 1.6 & 0 & 5 \\
\hline park & 5 & 8.4 & 94 & 50 & relentless & 1 & 0.6 & 5 & 4 \\
\hline parkay & 0 & 0.2 & 0 & 0 & relettered & 0 & 0.2 & 0 & 0 \\
\hline parking & 1 & 1.0 & 31 & 0 & relevance & 0 & 0.2 & 10 & 0 \\
\hline parlay & 0 & 0.4 & 0 & 0 & relevant & 2 & 4.8 & 23 & 0 \\
\hline parley & 1 & 0.6 & 1 & 2 & reliable & 1 & 1.8 & 22 & 10 \\
\hline parliament & 0 & 0.8 & 16 & 28 & reliant & 0 & 0.6 & 0 & 0 \\
\hline parliamentary & 0 & 0.2 & 8 & 5 & relic & 3 & 2.6 & 6 & 12 \\
\hline parlor & 0 & 2.4 & 18 & 30 & relief & 1 & 1.6 & 66 & 50 \\
\hline parlour & 0 & 0.2 & 0 & 0 & relieve & 3 & 5.2 & 13 & 46 \\
\hline parmesan & 0 & 0.4 & 0 & 0 & relight & 0 & 1.0 & 0 & 0 \\
\hline parody & 1 & 0.4 & 4 & 1 & religion & 8 & 2.0 & 119 & 50 \\
\hline parole & 0 & 0.2 & 5 & 3 & religious & 2 & 0.4 & 165 & 50 \\
\hline parrot & 8 & 3.4 & 1 & 9 & reline & 1 & 0.0 & 0 & 0 \\
\hline parry & 0 & 0.6 & 1 & 3 & relinquish & 3 & 6.8 & 6 & 5 \\
\hline parse & 1 & 0.2 & 0 & 0 & relish & 18 & 8.4 & 8 & 10 \\
\hline parsec & 0 & 0.2 & 0 & 0 & relive & 2 & 5.8 & 2 & 0 \\
\hline parsimonious & 0 & 1.0 & 1 & 0 & relived & 0 & 0.2 & 0 & 0 \\
\hline parsimony & 0 & 0.2 & 1 & 0 & reload & 0 & 1.6 & 0 & 1 \\
\hline parsing & 0 & 0.2 & 0 & 0 & relocate & 1 & 4.0 & 0 & 0 \\
\hline parsley & 2 & 2.4 & 1 & 8 & reluctance & 0 & 0.2 & 5 & 5 \\
\hline parsnip & 0 & 1.0 & 0 & 1 & reluctant & 0 & 1.2 & 15 & 6 \\
\hline parson & 1 & 1.2 & 2 & 10 & rely & 18 & 7.8 & 13 & 13 \\
\hline part & 23 & 10.0 & 500 & 100 & other comp. & 1 & 8.4 & - & - \\
\hline partake & 1 & 6.4 & 1 & 7 & & & & & \\
\hline partial & 1 & 2.0 & 11 & 9 & resale & 0 & 1.2 & 2 & 0 \\
\hline
\end{tabular}




\begin{tabular}{|c|c|c|c|c|c|c|c|c|c|}
\hline \multirow[b]{2}{*}{ Word } & \multicolumn{4}{|c|}{ Frequency } & \multirow[b]{2}{*}{ Word } & \multicolumn{4}{|c|}{ Frequency } \\
\hline & $\begin{array}{l}\text { 1st } \\
\text { Comp. }\end{array}$ & $\begin{array}{c}\text { 2nd-6th } \\
\text { Comp. }\end{array}$ & $K \& F$ & T\&L & & $\begin{array}{l}\text { 1st } \\
\text { Comp. }\end{array}$ & $\begin{array}{c}\text { 2nd-6th } \\
\text { Comp. }\end{array}$ & $K \& F$ & $=T \& L$ \\
\hline reschedule & 0 & 0.2 & 0 & 0 & resting & 0 & 0.2 & 19 & 0 \\
\hline rescind & 0 & 0.2 & 2 & 1 & restitution & 0 & 2.0 & 1 & \\
\hline rescue & 0 & 2.4 & 15 & 30 & restive & 0 & 0.2 & 1 & \\
\hline reseal & 0 & 0.2 & 0 & 0 & restless & 0 & 0.4 & 13 & 23 \\
\hline research & 1 & 0.2 & 171 & 22 & restoration & 0 & 0.6 & 11 & 11 \\
\hline rese1l & 0 & 0.2 & 0 & 0 & restore & 1 & 3.2 & 9 & 49 \\
\hline resemble & 0 & 0.6 & 8 & 29 & restrain & 0 & 0.4 & 10 & 19 \\
\hline resent & 0 & 1.6 & 8 & 16 & restraint & 1 & 0.2 & 11 & 11 \\
\hline reservation & 1 & 0.8 & 8 & 17 & restrict & 1 & 0.6 & 11 & 9 \\
\hline reserve & 3 & 2.0 & 37 & 50 & restructure & 0 & 0.2 & 0 & 0 \\
\hline reservoir & 0 & 2.2 & 10 & 8 & resubmit & 0 & 0.2 & 0 & 0 \\
\hline reset & 0 & 2.4 & 0 & 0 & result & 0 & 0.4 & 244 & 100 \\
\hline reshape & 0 & 0.4 & 0 & 0 & resume & 2 & 4.4 & 16 & 27 \\
\hline reshuffle & 0 & 0.2 & 0 & 0 & resurgence & 0 & 0.2 & 3 & 0 \\
\hline reside & 9 & 3.2 & 2 & 12 & resurrect & 0 & 1.2 & 0 & 0 \\
\hline residence & 3 & 1.0 & 29 & 25 & resurrection & 1 & 1.2 & 1 & 3 \\
\hline resident & 28 & 5.0 & 13 & 14 & resuscitate & 0 & 0.2 & 0 & 0 \\
\hline residential & 0 & 0.2 & 45 & 2 & resuscitation & 0 & 0.2 & 0 & 0 \\
\hline residual & 0 & 2.8 & 1 & 0 & other comp. & 0 & 5.2 & - & - \\
\hline residuals & 0 & 0.2 & 0 & 0 & & & & & \\
\hline residue & 3 & 4.4 & 8 & 2 & retail & 1 & 3.2 & 20 & ? \\
\hline resign & 0 & 3.0 & 2 & 26 & retain & 12 & 6.8 & 11 & 36 \\
\hline resilience & 0 & 0.2 & 1 & 0 & retainer & 0 & 0.2 & 0 & 4 \\
\hline resilient & 0 & 0.6 & 0 & 0 & retake & 3 & 7.2 & 0 & 1 \\
\hline resin & 1 & 1.6 & 9 & 3 & retaliate & 2 & 3.0 & 1 & 2 \\
\hline resist & 4 & 3.4 & 22 & 29 & retard & 0 & 2.2 & 3 & \\
\hline resistance & 0 & 0.8 & 48 & 26 & retarded & 1 & 0.6 & 7 & 0 \\
\hline resolute & 0 & 0.2 & 4 & 8 & retaste & 0 & 0.2 & 0 & 0 \\
\hline resolution & 1 & 1.6 & 64 & 27 & retch & 0 & 0.2 & 1 & 0 \\
\hline resolve & 0 & 2.6 & 13 & 39 & retell & 0 & 3.6 & 1 & 0 \\
\hline resonance & 1 & 1.0 & 14 & 1 & retention & 6 & 2.0 & 12 & 1 \\
\hline resonate & 1 & 0.2 & 0 & 1 & retest & 0 & 1.2 & 0 & 0 \\
\hline resort & 0 & 1.4 & 12 & 29 & rethink & 0 & 0.6 & 2 & 0 \\
\hline resound & 0 & 1.8 & 0 & 9 & reticence & 2 & 0.4 & 0 & 2 \\
\hline resource & 0 & 1.4 & 9 & 20 & reticent & 2 & 1.8 & 0 & 1 \\
\hline respect & 0 & $2 \cdot 6$ & 125 & 50 & reticular & 0 & 0.2 & 0 & 0 \\
\hline respectable & 0 & 0.6 & 21 & 13 & reticulate & 0 & 0.4 & 3 & 0 \\
\hline respiration & 2 & 1.8 & 2 & 4 & reticulated & 0 & 0.2 & 0 & 0 \\
\hline respirator & 0 & 0.4 & 0 & 0 & reticulum & 1 & 0.4 & 0 & 0 \\
\hline respiratory & 1 & 0.6 & 17 & 1 & retina & 11 & 6.8 & 1 & 1 \\
\hline respire & 2 & 0.2 & 0 & 0 & retinue & 1 & 0.6 & 1 & 3 \\
\hline respite & 0 & 1.0 & 2 & 4 & retire & 36 & 3.6 & 9 & 48 \\
\hline respond & 1 & 1.6 & 21 & 23 & retired & 1 & 0.0 & 35 & 4 \\
\hline response & 0 & 1.0 & 77 & 18 & retold & 0 & 0.6 & 1 & 0 \\
\hline responsible & 0 & 0.6 & 71 & 35 & retool & 0 & 0.2 & 0 & 0 \\
\hline rest & 26 & 9.2 & 163 & 100 & retort & 1 & 1.0 & 4 & 15 \\
\hline restart & 0 & 1.0 & 0 & 0 & retouch & 0 & 0.6 & 0 & 1 \\
\hline restate & 0 & 0.8 & 0 & 0 & retrace & 0 & 2.4 & 1 & 3 \\
\hline restaurant & 6 & 6.2 & 41 & 23 & retrack & 0 & 0.2 & 0 & 0 \\
\hline restful & 0 & 0.2 & 3 & 3 & retract & 1 & 1.2 & 0 & 2 \\
\hline
\end{tabular}




\begin{tabular}{|c|c|c|c|c|c|c|c|c|c|}
\hline \multirow[b]{2}{*}{ Word } & \multicolumn{4}{|c|}{ Frequency } & \multirow[b]{2}{*}{ Word } & \multicolumn{4}{|c|}{ Frequency } \\
\hline & $\begin{array}{c}\text { 1st } \\
\text { Comp. }\end{array}$ & $\begin{array}{l}\text { 2nd-6th } \\
\text { Comp. }\end{array}$ & $K \& F$ & $T \& L$ & & $\begin{array}{l}\text { 1st } \\
\text { Comp. }\end{array}$ & $\begin{array}{c}\text { 2nd-6th } \\
\text { Comp. }\end{array}$ & K\&F & T\&L \\
\hline retractable & 0 & 0.4 & 0 & 0 & salutary & 0 & 0.2 & 5 & 2 \\
\hline retrain & 0 & 2.0 & 0 & 0 & salutation & 1 & 1.8 & 1 & 5 \\
\hline retread & 0 & 2.0 & 0 & 0 & salutations & 0 & 0.4 & 0 & 0 \\
\hline retreat & 1 & 2.6 & 14 & 37 & salute & 10 & 9.0 & 3 & 22 \\
\hline retrial & 0 & 0.2 & 0 & 0 & salvage & 1 & 3.0 & 5 & 3 \\
\hline retribute & 0 & 0.6 & 0 & 0 & salvation & 2 & 2.0 & 32 & 10 \\
\hline retribution & 1 & 1.2 & 4 & 1 & salve & 0 & 2.2 & 3 & 3 \\
\hline retried & 0 & 0.2 & 0 & 0 & salvo & 0 & 0.6 & 2 & 0 \\
\hline retrieve & 1 & 3.0 & 2 & 3 & other comp. & 0 & 9.4 & - & - \\
\hline retrim & 0 & 0.2 & 0 & 0 & & & & & \\
\hline retroaction & 0 & 0.2 & 0 & 0 & scab & 8 & 9.8 & 0 & 1 \\
\hline retroactive & 0 & 4.2 & 0 & 0 & scabs & 0 & 0.2 & 0 & 0 \\
\hline retrograde & 0 & 1.6 & 3 & 1 & scaffold & 0 & 2.2 & 6 & 3 \\
\hline retrospect & 1 & 1.2 & 3 & 1 & scalar & 1 & 0.4 & 2 & 0 \\
\hline retrospection & 0 & 0.2 & 0 & 0 & scalawag & 1 & 0.0 & 0 & 0 \\
\hline retrospective & 0 & 0.4 & 1 & 0 & scald & 0 & 3.0 & 1 & 6 \\
\hline retry & 0 & 0.6 & 0 & 0 & scale & 13 & 8.4 & 60 & 50 \\
\hline return & 15 & 9.8 & 180 & 100 & scaling & 0 & 0.2 & 0 & 0 \\
\hline returnable & 0 & 0.6 & 0 & 0 & scallion & 0 & 0.6 & 0 & 0 \\
\hline returning & 0 & 0.2 & 35 & 0 & scallop & 0 & 1.6 & 0 & 4 \\
\hline other comp. & 0 & 16.8 & - & - & scallops & 0 & 0.8 & 1 & 0 \\
\hline & & & & & scalp & 1 & 1.6 & 4 & 10 \\
\hline salability & 0 & 0.2 & 0 & 0 & scalpel & 0 & 1.4 & 0 & 0 \\
\hline salable & 0 & 0.6 & 1 & 0 & scam & 9 & 9.2 & 0 & 0 \\
\hline salacious & 0 & 0.4 & 2 & 0 & scamp & 2 & 1.0 & 0 & 1 \\
\hline salad & 18 & 9.2 & 9 & 28 & scamper & 2 & 1.2 & 0 & 7 \\
\hline salamander & 2 & 5.6 & 2 & 2 & scampered & 0 & 0.2 & 0 & 0 \\
\hline salami & 0 & 2.0 & 7 & 0 & scan & 7 & 7.0 & 5 & 8 \\
\hline salary & 3 & 2.2 & 43 & 50 & scandal & 4 & 1.4 & 8 & 13 \\
\hline sale & 26 & 9.2 & 44 & 50 & scandinavia & 0 & 0.2 & 1 & 1 \\
\hline salem & 0 & 0.4 & 19 & 4 & scanner & 1 & 0.8 & 0 & 0 \\
\hline salesman & 0 & 0.2 & 12 & 16 & scansion & 0 & 0.2 & 0 & 0 \\
\hline salesmen & 0 & 0.2 & 19 & 0 & scant & 2 & 2.8 & 5 & 9 \\
\hline salient & 6 & 2.8 & 4 & 2 & scanty & 0 & 1.0 & 4 & 10 \\
\hline saline & 1 & 1.4 & 31 & 1 & scape & 2 & 2.0 & 0 & 0 \\
\hline salinity & 0 & 0.2 & 0 & 0 & scapegoat & 3 & 3.6 & 1 & 1 \\
\hline salisbury & 0 & 1.4 & 5 & 4 & scapula & 0 & 0.2 & 0 & 0 \\
\hline saliva & 2 & 4.0 & 4 & 3 & scapulary & 0 & 0.2 & 0 & 0 \\
\hline salivary & 1 & 0.4 & 1 & 0 & scar & 10 & 7.2 & 10 & 17 \\
\hline salivate & 2 & $4 \cdot 6$ & 1 & 0 & scarce & 0 & 2.8 & 6 & 27 \\
\hline salk & 0 & 0.2 & 1 & 0 & scarcity & 0 & 0.2 & 3 & 9 \\
\hline sallow & 0 & 1.8 & 1 & 3 & scare & 19 & 8.0 & 3 & 37 \\
\hline sally & 2 & 0.2 & 13 & 28 & scared & 3 & 1.4 & 21 & 0 \\
\hline salmon & 1 & 6.4 & 3 & 14 & scarf & 1 & 2.6 & 4 & 14 \\
\hline salon & 0 & 2.0 & 1 & 5 & scarlet & 0 & 0.2 & 3 & 27 \\
\hline saloon & 0 & 1.8 & 12 & 12 & scary & 1 & 0.4 & 2 & 0 \\
\hline salsa & 0 & 2.0 & 0 & 0 & scat & 2 & 4.6 & 0 & 0 \\
\hline salt & 20 & 10.6 & 46 & 100 & scathe & 1 & 1.4 & 0 & 0 \\
\hline salty & 2 & 1.2 & 4 & 1 & scathing & 1 & 0.2 & 1 & 0 \\
\hline salubrious & 0 & 0.4 & 2 & 0 & scatter & 4 & 4.8 & 2 & 50 \\
\hline
\end{tabular}




\begin{tabular}{|c|c|c|c|c|c|c|c|c|c|}
\hline \multirow[b]{2}{*}{ Word } & \multicolumn{4}{|c|}{ Frequency } & \multirow[b]{2}{*}{ Word } & \multicolumn{4}{|c|}{ Frequency } \\
\hline & $\begin{array}{l}\text { 1st } \\
\text { Comp. }\end{array}$ & $\begin{array}{c}\text { 2nd-6th } \\
\text { Comp. }\end{array}$ & $K \& F$ & T\&L & & $\begin{array}{c}1 s t \\
\text { Comp. }\end{array}$ & $\begin{array}{l}\text { 2nd-6th } \\
\text { Comp. }\end{array}$ & K\&F & $T \& L$ \\
\hline scattered & 0 & 0.2 & 27 & 0 & shah & 2 & 0.0 & 2 & 1 \\
\hline scavenger & 1 & 0.6 & 1 & 1 & shake & 10 & 6.4 & 17 & 50 \\
\hline other comp. & 1 & 4.8 & - & - & shaking & 0 & 0.2 & 21 & 0 \\
\hline & & & & & shale & 0 & 2.4 & 0 & 5 \\
\hline $\operatorname{scoff}$ & 4 & 6.2 & 0 & 8 & sha11 & 2 & 4.2 & 267 & 100 \\
\hline scoffer & 1 & 0.2 & 0 & 0 & shallot & 0 & 0.4 & 0 & 0 \\
\hline scold & 12 & 5.8 & 0 & 19 & shallow & 3 & $4 \cdot 6$ & 14 & 27 \\
\hline scolding & 0 & 0.4 & 2 & 0 & shalom & 0 & 0.2 & 1 & 0 \\
\hline scoliosis & 1 & 0.2 & 0 & 0 & sham & 8 & 2.4 & 1 & 3 \\
\hline sconce & 0 & 0.2 & 0 & 0 & shaman & 0 & 0.2 & 0 & 0 \\
\hline scone & 3 & 3.8 & 0 & 0 & shamble & 1 & 0.2 & 0 & 0 \\
\hline scones & 0 & 0.2 & 0 & 0 & shambles & 0 & 1.6 & 0 & 2 \\
\hline scoop & 3 & 7.4 & 5 & 8 & shame & 20 & 9.0 & 21 & 50 \\
\hline scooping & 1 & 0.0 & 1 & 0 & shampoo & 2 & 1.0 & 2 & 1 \\
\hline$s \operatorname{coot}$ & 0 & 2.6 & 0 & 0 & shamrock & 0 & 0.2 & 3 & 0 \\
\hline scooter & 1 & 4.0 & 0 & 0 & shan't & 0 & 0.8 & 1 & 5 \\
\hline scope & 32 & 11.2 & 27 & 11 & shank & 1 & 1.0 & 1 & 2 \\
\hline scorch & 1 & 1.8 & 0 & 9 & shanty & 0 & 1.6 & 3 & 6 \\
\hline score & 28 & 12.2 & 66 & 50 & shape & 12 & 10.0 & 85 & 100 \\
\hline scoreboard & 0 & 0.2 & 4 & 0 & shard & 0 & 0.2 & 0 & 0 \\
\hline scored & 0 & 0.2 & 15 & 10 & share & 9 & 7.8 & 98 & 100 \\
\hline scoring & 0 & 0.2 & 5 & 0 & shark & 5 & 3.0 & 0 & 7 \\
\hline scorn & 2 & 6.6 & 4 & 31 & sharp & 1 & 3.4 & 72 & 50 \\
\hline scornful & 0 & 0.2 & 5 & 5 & sharpen & 1 & 0.0 & 1 & 12 \\
\hline scorpio & 1 & 0.2 & 0 & 0 & shasta & 0 & 0.2 & 0 & 1 \\
\hline scorpion & 3 & 1.8 & 0 & 3 & shat & 0 & 0.2 & 0 & 0 \\
\hline$s \cot$ & 0 & 0.4 & 1 & 13 & shatter & 0 & 2.2 & 2 & 16 \\
\hline scotch & 1 & 2.0 & 5 & 16 & shave & 6 & 4.2 & 6 & 12 \\
\hline scotland & 1 & 0.0 & 13 & 30 & shaw & 1 & 0.0 & 9 & 7 \\
\hline scot-free & 0 & 0.2 & 1 & 0 & shawl & 0 & 0.8 & 3 & 9 \\
\hline scottish & 0 & 1.8 & 10 & 9 & other comp. & 0 & 2.0 & - & - \\
\hline scoundrel & 2 & 1.6 & 1 & 5 & & & & & \\
\hline scour & 0 & 4.4 & 1 & 8 & shoal & 0 & 2.4 & 0 & 8 \\
\hline scourge & 0 & 0.6 & 2 & 10 & shock & 2 & 7.4 & 31 & 50 \\
\hline scout & 2 & 5.2 & 8 & 37 & shod & 0 & 2.0 & 2 & 3 \\
\hline scouting & 0 & 0.2 & 3 & 0 & shoddy & 0 & 1.8 & 1 & 1 \\
\hline scow & 0 & 0.2 & 0 & 3 & shoe & 18 & 4.6 & 14 & 100 \\
\hline scowl & 1 & 3.8 & 0 & 10 & shoes & 0 & 0.4 & 44 & 0 \\
\hline other comp. & 0 & 13.8 & - & - & shogun & 1 & 0.6 & 0 & 0 \\
\hline & & & & & shone & 0 & 5.0 & 5 & 34 \\
\hline shabby & 2 & 3.0 & 5 & 11 & shook & 0 & 1.2 & 57 & 50 \\
\hline shack & 3 & 8.4 & 1 & 7 & shoot & 2 & 4.8 & 27 & 50 \\
\hline shackle & 0 & 1.2 & 0 & 2 & shop & 6 & 11.2 & 63 & 100 \\
\hline shad & 0 & 0.2 & 0 & 1 & shopping & 0 & 0.2 & 27 & 0 \\
\hline shade & 2 & 7.0 & 28 & 100 & shore & 6 & 9.6 & 61 & 100 \\
\hline shadow & 3 & 3.2 & 36 & 50 & shorn & 0 & 0.4 & 0 & 4 \\
\hline shady & 0 & 0.4 & 1 & 12 & short & 1 & 4.0 & 212 & 100 \\
\hline shaft & 6 & 3.6 & 11 & 25 & shot & 5 & 9.4 & 112 & 100 \\
\hline shag & 0 & 1.6 & 1 & 1 & should & 1 & 2.8 & 888 & 100 \\
\hline shaggy & 0 & 0.4 & 2 & 7 & shoulder & 0 & 2.6 & 61 & 100 \\
\hline
\end{tabular}




\begin{tabular}{|c|c|c|c|c|c|c|c|c|c|}
\hline \multirow[b]{2}{*}{ Word } & \multicolumn{4}{|c|}{ Frequency } & \multirow[b]{2}{*}{ Word } & \multicolumn{4}{|c|}{ Frequency } \\
\hline & $\begin{array}{c}\text { 1st } \\
\text { Comp. }\end{array}$ & $\begin{array}{c}\text { 2nd-6th } \\
\text { Comp. }\end{array}$ & K\&F & $=T \& L$ & & $\begin{array}{c}\text { 1st } \\
\text { Comp. }\end{array}$ & $\begin{array}{r}\text { 2nd-6th } \\
\text { Comp. }\end{array}$ & K\&F & E T\&L \\
\hline shout & 3 & 5.2 & 9 & 100 & tenacity & 0 & 0.8 & 5 & 1 \\
\hline shove & 2 & 4.6 & 2 & 15 & tenant & 8 & 3.0 & 5 & 16 \\
\hline shoved & 0 & 0.2 & 8 & 0 & tend & 1 & 7.6 & 43 & 50 \\
\hline shovel & 1 & 1.8 & 5 & 14 & tendency & 0 & 1.2 & 49 & 27 \\
\hline show & 45 & 7.0 & 287 & 100 & tender & 13 & 8.8 & 11 & 50 \\
\hline shower & 6 & 6.0 & 15 & 41 & tenderizer & 0 & 0.2 & 0 & 0 \\
\hline showmanship & 0 & 0.2 & 11 & 0 & tending & 0 & 0.2 & 4 & 0 \\
\hline shown & 1 & 1.4 & 166 & 50 & tendon & 1 & 3.2 & 0 & 2 \\
\hline \multirow[t]{2}{*}{ other comp. } & 0 & 2.8 & - & - & tendonitis & 0 & 0.2 & 0 & 0 \\
\hline & & & & & tendril & 0 & 0.2 & 0 & 2 \\
\hline spic & 1 & 1.4 & 1 & 0 & tendrils & 0 & 0.2 & 0 & 0 \\
\hline spice & 6 & 6.2 & 4 & 17 & tenement & 0 & 1.2 & 2 & 8 \\
\hline spices & 1 & 0.0 & 3 & 0 & tenfold & 1 & 0.4 & 1 & I \\
\hline spick & 0 & 0.6 & 0 & 0 & tennis & 14 & 7.0 & 15 & 18 \\
\hline spicket & 0 & 1.0 & 0 & 0 & tenor & 5 & 6.6 & 6 & 6 \\
\hline spicule & 0 & 0.2 & 0 & 0 & tenpin & 0 & 0.6 & 0 & 0 \\
\hline spider & 14 & 4.8 & 2 & 24 & tens & 0 & 0.2 & 1 & 0 \\
\hline spied & 5 & 1.0 & 0 & 0 & tense & 5 & 7.2 & 15 & 9 \\
\hline spies & 9 & 2.2 & 2 & 0 & tensile & 0 & 0.8 & 5 & 0 \\
\hline spiffy & 0 & 2.0 & 0 & 0 & tension & 2 & 5.6 & 59 & 9 \\
\hline spigot & 0 & 1.8 & 0 & 1 & tensor & 0 & 0.2 & 0 & 0 \\
\hline spike & 7 & 5.6 & 2 & 5 & tent & 21 & 10.6 & 20 & 50 \\
\hline spikes & 0 & 0.2 & 3 & 0 & tentacle & 1 & 1.8 & 1 & 3 \\
\hline spill & 7 & 11.4 & 1 & 12 & tentacles & 0 & 0.4 & 2 & 0 \\
\hline spilt & 0 & 0.4 & 0 & 2 & tentation & 0 & 0.2 & 0 & 0 \\
\hline spin & 12 & 13.6 & 5 & 24 & tentative & 6 & 8.0 & 15 & 3 \\
\hline spinach & 0 & 2.0 & 2 & 8 & tentatively & 1 & 0.4 & 6 & 0 \\
\hline spinal & 0 & 0.2 & 0 & 4 & tenth & 3 & 2.4 & 7 & 23 \\
\hline spindle & 3 & 4.4 & 8 & 9 & tenths & 0 & 0.2 & 1 & 0 \\
\hline spine & 5 & 6.8 & 6 & 10 & tenuous & 0 & 0.4 & 6 & 0 \\
\hline spineless & 0 & 0.2 & 2 & 0 & tenure & 4 & 4.4 & 12 & 2 \\
\hline spinnaker & 0 & 0.6 & 0 & 0 & other comp. & 6 & 10.2 & - & - \\
\hline spinner & 0 & 0.4 & 0 & 3 & & & & & \\
\hline spinning & 0 & 0.2 & 11 & 11 & thiamin & 0 & 0.4 & 1 & 0 \\
\hline spinster & 0 & 2.4 & 0 & 2 & thiamine & 0 & 0.8 & 0 & 0 \\
\hline spiral & 0 & 1.8 & 8 & 6 & thick & 7 & 14.2 & 67 & 50 \\
\hline spire & 0 & 1.8 & 5 & 11 & thicken & 0 & 0.4 & 1 & 5 \\
\hline spirit & 5 & 3.6 & 182 & 100 & thicket & 0 & 1.0 & 1 & 19 \\
\hline spiritual & 0 & 0.4 & 64 & 21 & thief & 2 & 2.6 & 8 & 28 \\
\hline spirt & 0 & 0.8 & 0 & 0 & thigh & 7 & 4.4 & 9 & 13 \\
\hline spit & 20 & 13.0 & 11 & 13 & thill & 0 & 0.2 & 0 & 0 \\
\hline spite & 5 & 4.8 & 56 & 50 & thimble & 3 & 8.2 & 1 & 4 \\
\hline spiteful & 0 & 0.2 & 0 & 3 & thin & 7 & 14.2 & 92 & 100 \\
\hline spitting & 0 & 0.2 & 5 & 0 & thine & 0 & 1.4 & 1 & 19 \\
\hline spittle & 0 & 0.8 & 2 & 0 & thing & 11 & 5.6 & 333 & 100 \\
\hline spittoon & 0 & 0.8 & 0 & 0 & think & 15 & 9.6 & 433 & 100 \\
\hline \multirow[t]{2}{*}{ other comp. } & 1 & 2.6 & - & - & thinking & 0 & 0.2 & 145 & 50 \\
\hline & & & & & third & 10 & 4.6 & 190 & 100 \\
\hline tenable & 0 & 0.2 & 4 & 0 & thirst & 4 & 4.8 & 4 & 23 \\
\hline tenacious & 8 & 5.2 & 1 & 2 & thirsty & 0 & 1.8 & 5 & 11 \\
\hline
\end{tabular}




\begin{tabular}{|c|c|c|c|c|c|c|c|c|c|}
\hline \multirow[b]{2}{*}{ Word } & \multicolumn{4}{|c|}{ Frequency } & \multirow[b]{2}{*}{ Word } & \multicolumn{4}{|c|}{ Frequency } \\
\hline & $\begin{array}{c}\text { 1st } \\
\text { Comp. }\end{array}$ & $\begin{array}{c}\text { 2nd-6th } \\
\text { Comp. }\end{array}$ & K\&F & F T\&L & & $\begin{array}{c}\text { 1st } \\
\text { Comp. }\end{array}$ & $\begin{array}{c}\text { 2nd-6th } \\
\text { Comp. }\end{array}$ & K\&F & $=T \& L$ \\
\hline thirteen & 0 & 0.2 & 11 & 34 & tragic & 2 & 1.6 & 33 & 16 \\
\hline thirty & 1 & 1.8 & 59 & 100 & trail & 5 & 8.0 & 31 & 50 \\
\hline this & 30 & 7.6 & 5146 & 100 & trailer & 0 & 0.6 & 11 & 5 \\
\hline thistle & 2 & 6.6 & 0 & 8 & train & 20 & 10.2 & 82 & 100 \\
\hline thither & 0 & 0.6 & 1 & 25 & trainer & 0 & 0.2 & 0 & 15 \\
\hline \multirow[t]{2}{*}{ other comp. } & 1 & 8.2 & - & - & traipse & 1 & 0.8 & 0 & 0 \\
\hline & & & & & trait & 0 & 2.6 & 3 & 7 \\
\hline thrash & 5 & 5.8 & 1 & 10 & traitor & 0 & 0.4 & 2 & 21 \\
\hline thread & 2 & 4.0 & 15 & 50 & trajectory & 0 & 0.6 & 2 & 0 \\
\hline threat & 2 & 5.0 & 42 & 17 & tram & 2 & 8.0 & 0 & 1 \\
\hline threaten & 0 & 1.2 & 11 & 50 & tramp & 2 & 3.6 & 1 & 24 \\
\hline threatening & 0 & 0.2 & 26 & 0 & trample & 0 & 2.2 & 3 & 15 \\
\hline three & 15 & 8.8 & 610 & 100 & trampoline & 0 & 0.4 & 0 & 0 \\
\hline threshold & 2 & 1.4 & 15 & 13 & tramway & 0 & 0.2 & 1 & 1 \\
\hline threw & 3 & 3.2 & 46 & 50 & trance & 0 & 1.4 & 4 & 5 \\
\hline thrice & 0 & $4 \cdot 0$ & 1 & 12 & tranquil 1 & 0 & 0.2 & 2 & 6 \\
\hline thrift & 2 & 2.0 & 5 & 7 & tranquility & 0 & 0.2 & 4 & 6 \\
\hline thriftily & 0 & 0.2 & 0 & 1 & tranquilizer & 0 & 0.4 & 1 & 0 \\
\hline thrifty & 4 & 1.6 & 3 & 5 & trans & 0 & 0.4 & 0 & 0 \\
\hline thrill & 3 & 4.6 & 5 & 46 & transcend & 0 & 2.2 & 1 & 1 \\
\hline thrilling & 0 & 0.4 & 4 & 0 & transcendental & 0 & 0.2 & 3 & 0 \\
\hline thrip & 0 & 0.2 & 0 & 0 & transcontinent & 0 & 0.2 & 0 & 3 \\
\hline thrist & 0 & 0.6 & 0 & 0 & transfer & 0 & 1.2 & 38 & 28 \\
\hline thrive & 4 & 6.4 & 1 & 16 & transform & 0 & 0.2 & 7 & 17 \\
\hline thro & 0 & 0.2 & 2 & 5 & transient & 0 & 0.4 & 3 & 5 \\
\hline throat & 3 & 4.8 & 51 & 50 & transistor & 0 & 0.6 & 1 & 0 \\
\hline throb & 0 & 1.8 & 0 & 9 & transit & 0 & 1.0 & 16 & 5 \\
\hline thrombosis & 0 & 0.2 & 1 & 0 & transmit & 0 & 0.4 & 3 & 9 \\
\hline throne & 0 & 1.4 & 5 & 43 & transom & 0 & 0.2 & 17 & 0 \\
\hline throng & 0 & 2.4 & 3 & 21 & transpire & 0 & 0.2 & 0 & 2 \\
\hline throttle & 0 & 2.0 & 6 & 3 & transport & 0 & 1.4 & 18 & 28 \\
\hline through & 24 & 10.6 & 969 & 100 & transportation & 0 & 0.2 & 43 & 25 \\
\hline throughout & 0 & 0.2 & 141 & 50 & transverse & 0 & 0.2 & 4 & 2 \\
\hline throw & 26 & 9.4 & 42 & 50 & transvestite & 1 & 0.0 & 0 & 0 \\
\hline thrown & 0 & 0.2 & 40 & 50 & trap & 14 & 6.6 & 20 & 42 \\
\hline thru & 1 & 1.0 & 10 & 4 & trapeze & 0 & 0.2 & 0 & 0 \\
\hline thrush & 0 & 0.6 & 2 & 6 & trapezoid & 0 & 0.2 & 1 & 0 \\
\hline thrust & 1 & 4.4 & 22 & 40 & trapped & 0 & 0.2 & 7 & 0 \\
\hline \multirow[t]{2}{*}{ other comp. } & 3 & 9.8 & - & - & trash & 9 & 3.0 & 2 & 3 \\
\hline & & & & & trauma & 2 & 0.6 & 1 & 0 \\
\hline trace & 9 & 5.4 & 23 & 50 & traumatic & 1 & 0.0 & 1 & 0 \\
\hline trachea & 0 & 0.8 & 2 & 0 & travel & 8 & 3.6 & 61 & 100 \\
\hline tracheotomy & 1 & 0.0 & 0 & 0 & traverse & 1 & 1.4 & 5 & 16 \\
\hline track & 4 & 11.6 & 38 & 50 & travesty & 0 & 0.2 & 1 & 1 \\
\hline tractor & 1 & 1.0 & 24 & 12 & trawl & 0 & 0.4 & 0 & 0 \\
\hline trade & 11 & 8.2 & 143 & 100 & tray & 2 & 2.6 & 18 & 17 \\
\hline trading & 0 & 0.2 & 25 & 0 & other comp. & 1 & 1.6 & - & - \\
\hline tradition & 1 & 1.2 & 94 & 37 & & & & & \\
\hline traffic & 2 & 1.8 & 68 & 36 & triacetate & 0 & 0.2 & 0 & 0 \\
\hline tragedy & 0 & 0.2 & 49 & 27 & triad & 1 & 1.2 & 1 & 0 \\
\hline
\end{tabular}




\begin{tabular}{|c|c|c|c|c|c|c|c|c|c|}
\hline \multirow[b]{2}{*}{ Word } & \multicolumn{4}{|c|}{ Frequency } & \multirow[b]{2}{*}{ Word } & \multicolumn{4}{|c|}{ Frequency } \\
\hline & $\begin{array}{c}\text { 1st } \\
\text { Comp. }\end{array}$ & $\begin{array}{c}\text { 2nd-6th } \\
\text { Comp. }\end{array}$ & $K \& F$ & T\&L & & $\begin{array}{c}\text { 1st } \\
\text { Comp. }\end{array}$ & $\begin{array}{c}\text { 2nd-6th } \\
\text { Comp. }\end{array}$ & K\&F & F T\&L \\
\hline triage & 0 & 0.2 & 0 & 0 & trip & 9 & 8.6 & 81 & 100 \\
\hline trial & 4 & 3.6 & 134 & 50 & tripe & 0 & 1.2 & 1 & 1 \\
\hline trials & 0 & 0.2 & 39 & 0 & triphosphate & 0 & 0.2 & 0 & 0 \\
\hline triangle & 15 & 2.2 & 4 & 8 & triple & 17 & 3.6 & 5 & 6 \\
\hline triangular & 0 & 0.2 & 5 & 4 & triplet & 1 & 0.4 & 1 & 0 \\
\hline triathalon & 2 & 0.2 & 0 & 0 & triplicate & 0 & 0.4 & 0 & 0 \\
\hline tribe & 2 & 5.6 & 4 & 50 & tripod & 3 & 2.2 & 3 & 2 \\
\hline tribulate & 0 & 0.2 & 0 & 0 & triscuit & 0 & 0.2 & 0 & 0 \\
\hline tribulation & 0 & 0.6 & 1 & 2 & trisect & 0 & 0.2 & 0 & 0 \\
\hline tribunal & 0 & 1.2 & 5 & 9 & trisemester & 0 & 0.2 & 0 & 0 \\
\hline tribune & 0 & 0.4 & 13 & 5 & trite & 7 & 3.8 & 2 & 1 \\
\hline tribute & 0 & 1.2 & 24 & 22 & triton & 3 & 0.8 & 0 & 1 \\
\hline triceps & 0 & 0.4 & 0 & 0 & triumph & 3 & 1.0 & 22 & 41 \\
\hline triceratops & 0 & 0.2 & 0 & 0 & triumphant & 0 & 0.4 & 5 & 9 \\
\hline trick & 5 & 11.4 & 15 & 50 & trivia & 1 & 0.0 & 2 & 0 \\
\hline trickle & 1 & 2.6 & 2 & 7 & trivial & 1 & 2.2 & 11 & 8 \\
\hline trickling & 0 & 0.2 & 2 & 0 & other comp. & 1 & 5.2 & - & - \\
\hline tricky & 0 & 0.2 & 1 & 1 & & & & & \\
\hline tricycle & 9 & 5.0 & 0 & 1 & & & & & \\
\hline trident & 1 & 1.2 & 0 & 1 & weak & 28 & 11.6 & 32 & 50 \\
\hline tried & 2 & 3.6 & 170 & 100 & weaken & 1 & 0.8 & 7 & 14 \\
\hline tries & 0 & 0.4 & 13 & 0 & weakening & 0 & 0.2 & 6 & 0 \\
\hline trifle & 1 & 3.2 & 9 & 24 & weaker & 0 & 0.2 & 8 & 0 \\
\hline trigger & 1 & 1.8 & 12 & 4 & weakling & 0 & 1.2 & 0 & 2 \\
\hline triglyceride & 0 & 0.2 & 0 & 0 & weakness & 1 & 0.4 & 46 & 37 \\
\hline trigonal & 0 & 0.2 & 2 & 0 & weal & 0 & 0.8 & 0 & 3 \\
\hline trigonometry & 0 & 2.6 & 0 & 0 & weald & 0 & 0.2 & 0 & 0 \\
\hline trike & 0 & 0.2 & 0 & 0 & wealth & 2 & 2.4 & 22 & 50 \\
\hline $\operatorname{tri11}$ & 1 & 1.4 & 3 & 3 & weal thy & 0 & 0.2 & 12 & 27 \\
\hline trilling & 0 & 0.2 & 0 & 0 & wean & 10 & 11.8 & 0 & 4 \\
\hline trillion & 0 & 0.6 & 1 & 0 & weaned & 0 & 0.2 & 1 & 0 \\
\hline trillium & 0 & 0.2 & 0 & 0 & weaner & 0 & 0.2 & 0 & 0 \\
\hline trilobite & 0 & 0.2 & 0 & 0 & weanie & 1 & 0.2 & 0 & 0 \\
\hline trilogy & 2 & 1.6 & 4 & 0 & weapon & 2 & 5.4 & 42 & 42 \\
\hline trim & 3 & 8.4 & 20 & 42 & wear & 11 & 13.4 & 36 & 100 \\
\hline trimaran & 0 & 0.8 & 0 & 0 & wearing & 0 & 0.2 & 47 & 0 \\
\hline trimester & 1 & 1.8 & 1 & 0 & weary & 2 & 5.4 & 17 & 38 \\
\hline trimethylamine & 1 & 0.0 & 0 & 0 & wease1 & 4 & 10.8 & 1 & 9 \\
\hline trinidad & 0 & 0.2 & 1 & 2 & weather & 17 & 7.2 & 69 & 100 \\
\hline trinity & 1 & 1.8 & 5 & 6 & weave & 17 & 7.8 & 4 & 22 \\
\hline trinket & 1 & 0.2 & 1 & 3 & weaver & 2 & 1.0 & 4 & 7 \\
\hline trinomial & 0 & 0.2 & 0 & 0 & weaving & 0 & 0.2 & 5 & 0 \\
\hline trio & 0 & 0.8 & 9 & 2 & other comp. & 2 & 18.2 & - & - \\
\hline
\end{tabular}

(Maruscript received April 16, 1987;

revision accepted for publication June 19, 1987.) 